Amasya Ilahiyat Dergisi - Amasya Theology Journal

ISSN 2667-7326 | e-ISSN 2667-6710

Haziran / June 2021, 16: 421-450

\title{
Arap Dilinde İsmin İkili Taksiminde Vâsıta Olgusu
}

\author{
Mahsum TAŞ \\ Dr. Öğr. Görevlisi, Siirt Üniversitesi, İlahiyat Fakültesi, \\ Arap Dili ve Belâgatı Anabilim Dalı \\ Ph.D Lecturer, Siirt University, Faculty of Theology, \\ Arabic Language and Rhetoric \\ Siirt, Turkey \\ ebulmina@hotmail.com \\ orcid.org/0000-0002-3158-8631
}

\section{Makale Bilgisi / Article Information}

Makale Türü / Article Types: Araştırma Makalesi / Research Article

Geliş Tarihi / Received: 25 Mart / March 2020

Kabul Tarihi / Accepted: 16 Nisan / April 2020

Yayın Tarihi / Published: 30 Haziran / June 2021

Yayın Sezonu / Pub. Date Season: Haziran / June

Sayı / Issue: 16 Sayfa / Pages: 421-450

Atıf / Cite as: Taş, Mahsum. “Arap Dilinde İsmin İkili Taksiminde Vâsıta Olgusu [The Dual Classicifationa the Phenomenon Vâsıta in Arabic Language]". Amasya Ilahiyat Dergisi-Amasya Theology Journal 16 (June 2021): 421-450.

https://doi.org/10.18498/amailad.903163.

Intihal / Plagiarism: Bu makale, en az iki hakem tarafından incelendi ve intihal içermediği teyit edildi. / This article has been reviewed by at least two referees and scanned via a plagiarism software.

Copyright @ Published by Amasya Üniversitesi, İlahiyat Fakültesi / Amasya University, Faculty of Theology, Amasya, 05100 Turkey. All rights reserved. https://dergipark.org.tr/amailad. 
422 I M. TAŞ / Arap Dilinde İsmin İkili Taksiminde Vâsıta Olgusu

\section{The Dual Classicifation the Phenomenon Vâstta in Arabic Language}

\section{Abstract}

In Arabic language, one of the main components that constitute sentences is nouns. Although the nouns are put into the dual classification such as " $m u$ 'rabmabni" or "marifah-nakirah", "zâhir-pronoun", "munsarif-gayr-i munsarif", the issues regarding which of those types include some nouns or whether they are within the scope of both categories have been debatable for certain nouns among the linguists. Therefore, a third classification which is called vâsita came to the fore. Despite the fact that some linguists don't accept such a type of nouns, different viewpoints on the nouns which aren't included into the dual classification are still popular among the linguists. In the research, the nouns

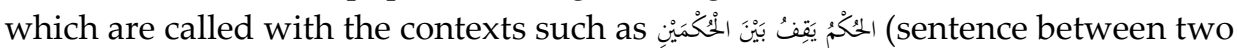
sentences), المنزلة بين منزلتين (a third position between two positions) and الواسطة (being in the middle) in grammar works as they are not included in dual classification were emphasized, and the viewpoints of linguists on them were included. As those nouns are stated with the term of "vâsita" in the aforementioned works, that term was preferred on the title of study. It is intended to introduce these nouns; to attract notice to the discussions of linguists on this issue and to provide the right viewpoint after evaluating them. According to some linguists, nominative nouns addressee nouns which are "mufrad-ma' rifah" and nakirah and maksud", nouns which are attributed to the first-person singular possessive pronoun, the word of سَحر that the dawn of a certain day is meant, the word of is adverb and proper, the proper nouns which come after مَن with the vowel point itbâ at its end and the interrogative and which take the related irâb are vâsita and neither mu'rab nor mabni. Some of linguists emphasized that the aforementioned nouns are associated with the mu'rab or mabni, so neither mu'rab nor mabni nouns can be out of the question. Moreover, some linguists mentioned the existence of some nouns which are not associated with the dual classification as "all of the nouns are either marifah or nakirah in Arabic language. So it was mentioned that the

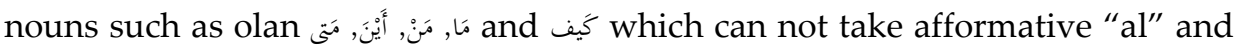
tenvin are neither marifah nor nakirah but they are vâsita. However, the view that nouns such as interrogatives كَيف مَ مَنْ , أَيْنَ , مَتَّ are associated with the nakirah nouns seems to be more right. The phenomenon vâsita was mentioned in terms that nouns are classified into two categories such as zâhir and pronoun and the pronouns are put into dual classification as discrete and adjoinant. According to the viewpoint, which is preferred, there are not nouns which are 
vâsita but neither zâhir nor pronoun in Arabic language in the context of dual classification as "zâhir-pronoun". However, this phenomenon can be mentioned in the classification "discrete-adjoinant". The phenomenon vâsita was discussed about the classification of proper nouns as "alem-i menkul and alem-i murtacal" and the classification of nouns into "munsarif" and "ghayr-i munsarif". The viewpoint which mentions the phenomenon vâsita in the aforementioned classifications seems to be more right. So the view that some nouns are not associated with two classifications while the nouns are related to the dual classifications with the different values comes up as not consisting of a suggestion. As a result, it is a forcing approach to mention that nouns are not included in dual classification such as either "mu'rab or mabni", either "marifah or nakirah" either "pronoun or zahir" but the nouns are vâsita. However, it is possible to mention about the nouns which are not associated with the dual classification as "Pronouns are either adjoinant or discrete", "nouns are either menkul or murtacal", "mu'rab nouns are either munsarif or gayr'i munsarif" but they are vâsita.

Keywords: Arabic Language and Rhetoric, Linguists, Classification Noun, Proper Noun, Phenomenon Vasita in Arabic Language.

\section{Öz}

\section{Arap Dilinde İsmin İkili Taksiminde Vâsıta Olgusu}

Arapçada cümleleri oluşturan temel ögelerden birisi de isimlerdir. İsimler her ne kadar "mu'reb-mebnî", "ma'rife-nekire", "zâhir-zamir", "munsarıf-gayr-1 munsarıf" gibi ikili taksimata tabi tutulmuşsa da bazı isimlerin bu türlerden hangisinin altına dâhil edileceği veya her iki taksimin kapsamina da girip girmediği hususları dilciler tarafından tartışma konusu olmuştur. Bu da "vâsıta" denilen ismin üçüncü bir konumunu gündeme getirmiştir. Bazı dilciler böyle bir isim türünü kabul etmese de ikili taksime dâhil edilemeyen isimler konusundaki farklı görüşler dilciler arasında gündemdeki yerini korumaktadır. Çalışmada,

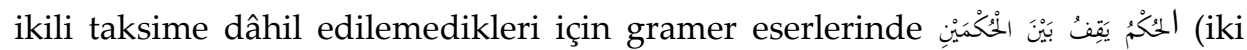
hüküm arasında yer alan hüküm), المنزلة بين منزلين (iki konum arasında üçüncü bir konuma) ve الواسطة (orta yerde duran) gibi kavramlarla dile getirilen isimler üzerinde durulmuş ve dilcilerin bunlar hakkındaki görüşlerine yer verilmiştir. Söz konusu eserlerde bu isimler daha çok "vâsıta" kavramıla ifade edildikleri için çalışmanın başlığında bu kavram tercih edilmiştir. Çalışmanın amacı bu 
isimleri tanıtmanın yanında dilcilerin bu konudaki tartışmalarına dikkat çekmek ve bunları değerlendirip isabetli olan görüşü ortaya koymaya çalışmaktır.

Bazı dilcilere göre yalın hâldeki isimler, müfred-ma'rife ve nekra-i maksûde olan münâdâ isimler, mütekellim yâ'sına izâfe edilen isimler, belirli bir günün seherinin kastedildiği سَحَر kelimesi, zarf ve alem olan أَمَِّ kelimesi, sonunda itbâ harekesi bulunan ve soru edatı olan مَن 'den sonra gelip mahkî irâb alan alem isimler vâsıta konumunda olup ne mu'rab ne de mebnîdir. Bazıları ise söz konusu isimlerin mu'rab veya mebnî isimlerin kapsamına girdiğini, dolayısıyla ne mu'rab ne de mebnî olan isimlerin söz konusu olamayacağını vurgulamışlardır. Yine bazı dilciler, Arap dilindeki tüm isimler "ya ma'rife veya nekiredir" şeklindeki ikili taksime dâhil olmayan bazı isimlerin varlığından söz etmişlerdir. Bu bağlamda "el" takısı ve tenvîn alamayan istifhâm edatları olan ,

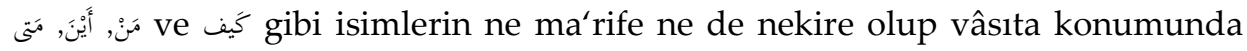

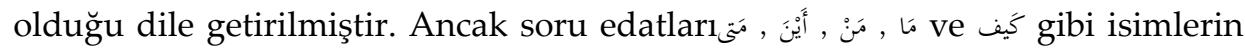
nekire isimlerin kapsamına girdiğine dair görüşün daha isabetli görünmektedir. İsimlerin zâhir ve zamir olmak üzere iki kısma ayrılması, zamirlerin muttasıl ve munfasıl şeklinde ikili taksime tabi tutulması bakımından da vasıta olgusundan söz edilmiştir. Tercih edilen görüşe göre isimlerin "zâhir-zamir" şeklindeki ikili taksimi bağlamında, Arap dilinde vâsıta konumunda olup ne zâhir ne de zamir olan isimler bulunmamaktadir. Ancak "muttasıl-munfasil" taksiminde bu olgudan söz edilebilmektedir. Özel isimlerin alem-i menkûl ve alem-i mürtecel olmak üzere iki kısma ayırılması ve isimlerin munsarıf ve gayr-1 munsarıf biçiminde iki kısma ayrılması hususlarında da vâsıta olgusu tartışılmıştır. Söz konusu iki taksimde de vâsita olgusundan söz eden görüşün daha isabetli görünmektedir. Bu bağlamda isimler farklı itibarlarla ikili taksimlere konu edilirken bazı isimlerin her iki taksimin altına da girmediğine dair görüşün bir iddiadan ibaret olmadığı ortaya çıkmaktadır.

Netice itibariyle isimler, "ya mu'reb veya mebnîdir", " ya ma' rife veya nekiredir", "ya zamir veya zâhirdir" şeklindeki ikili taksime dâhil olmayıp vâsıta konumunda olan isimlerden söz etmek zorlama bir yaklaşımdır. Ancak "zamirler ya muttasıl veya munfasıldır", "alemler ya menkûl veya mürteceldir", "mu'reb isimler ya munsarıf veya gayr-1 munsarıftır" biçimindeki ikili taksimin kapsamına girmeyip vâsıta konumunda olan isimlerden söz etmek ihtimal dahilindedir.

Anahtar Kelimeler: Arap Dili ve Belâgatı, Dilciler, İsmin Taksimi, Özel İsim, Arap Dilinde Vâsıta Olgusu. 


\section{Giriş}

Vâsıta kelimesi gَ veya vin masdarının ism-i fâil kalıbı olup sözlükte, "ortada olan”, "iki şeyin ortasında bulunan”, "bir şeyin iki ucu arasında bulunan", "iki şey arasında bağlantı kuran" ve "aracı" gibi anlamlara gelmektedir. ${ }^{1}$ Çalışmamızda bahsi geçen vâsıta ile isim "ya mu'reb ya mebnîdir, ya ma'rife ya nekiredir" gibi ikili taksime girmeyip üçüncü bir konuma sahip olan isimler kastedilmektedir.

Bazı dilciler, farklı itibarlarla ikili taksimleri konu edinirken bazı isimlerin her iki taksimin altına girmediğini iddia etmişlerdir. ${ }^{2}$ Bir kısım dilciler ise bu olguyu kabul etmemiştir. Onlara göre isimlerin ikili taksimlerinin haricinde herhangi bir kategoriye sahip olmaları söz konusu değildir. ${ }^{3}$

İbnu'ş-Şecerî (öl. 542/1148) bahse konu isimler için "menzile beyne'l-menzileteyn" tabirini kullanmıştır. Nitekim o, müfred márife münâdanın ne mu'reb ne de mebnî olduğuna, dolayısıyla bu ismin "iki konum arasında üçüncü bir konuma" sahip olduğuna işaret ederken بُ ifadesini kullanmıştır. ${ }^{4}$ Buna karşılık İbn Cinnî (öl. 392/1002) ismin ikili taksimine dâhil olmayanlar için الحُكْمُ يَقِفْ بَيْنَ الُْخْمَيْنِ (iki hüküm

1 Halîl b. Ahmed, Kitâbu'l-'ayn, thk. Abdülhamid Hindâvî (Beyrut: Dâru'l-Kutubi'l'İlmiyye, 1424/2003), 4/369-370; Ebu'l-Fadl Cemâlüddîn Muhammed b. Mükerrem İbn Manzûr, Lisânu'l-'Arab (Beyrut: Dâru Sâdır, 1414), "vasat", 7/426.

2 Bk. Ebü's-Saâdât Ziyâüddîn Hibetullah b. Alî b. Muhammed b. Hazma İbnü'ş-Şecerî, el-Emâlî, thk. Mahmûd Muhammed et-Tanâhî (Kahire: Mektebetü'l-Hâncî, ts.), 2/368; İbn Cinnî Ebu'l-Feth Osmân b. Cinnî el-Mevsılî, el-Hasâis (Kahire: el-Heyetü'l-Miriyye el-Âmme li'l-Kitâb, ts.), 2/358; Muhammed b. Yûsuf b. 'Alî b. Yûsuf b. Hayyân elEndelüsî, İrtişâfü'd-darab min lisâni'l- 'Arab, thk. Receb Osman Muhammed (Kahire: Mektebetu'l-Hancî, 1998), 2/870; Celâluddîn Abdurrahmân b. Ebî Bekr es-Süyûtî, elEşbâh ve'n-nezâir fi'n-nahv, thk. Abdulâl Sâlim Mükerrem (Beyrut: Müessesetu'r-Risâle, 1406), 2/368.

3 Bu görüş dilcilerin çoğunluğunun görüşüdür. Örnek için bk. Ebu'l-Bekâ Muhibbuddîn 'Abdullah b. el-Huseyn el-'Ukberî, el-Lubâb fì 'İleli'l-i'râbi ve'l-binấ', thk. 'Abdulillâh enNebhân (Dimaşk: Dru'l-Fikr, 1995), 1/67; Ebû Muhammed Cemâluddîn 'Abdullâh b. Yûsuf b. Hişâm el-Ensârî, Evdahu'l-mesâlik ilâ Elfiyyeti İbn Malik, thk. Yusuf eş-Şeyh Muhammed el-Bukâî (Beyrut: Daru'l-Fikri li't-Tibâ'ati ve'n-Neşr, ts.), 1/54; Ebû Muhammed Bedruddîn Hasan b. Kâsım b. 'Alî el-Murâdî, Tavdîhu'l-mesâlik ve'lmakâsid bi şerhi Elfiyyeti İbni Mâlik, thk. 'Abdurrahmân 'Alî Süleyman (Kahire: Dâru'lFikri'l-'Arabî, 2008), 1/297.

4 İbnü'ş-Şecerî, el-Emâlî, 2/368. 
arasında yer alan hüküm) kavramını kullanmıştır. ${ }^{5}$ Süyûtî (öl. 911/1505) ise "لواسطة" (orta yerde duran) ifadesini dile getirmiştir. Nitekim o, elEşbâh ve'n-Nazâir adlı eserinde "لواسطة" şeklinde bir başlık atmış ve sözü edilen taksime dâhil olmayan isimleri bu başlık altında ele almıştır. ${ }^{6}$ Gramer eserlerinde daha çok vâsıta kavramı kullanıldığı için çalışmamızda bu ifadeyi kullanmayı tercih ettik.

\section{Mu'rab ve Mebnî Taksiminde Vâsıta Olgusu}

Gramercilerin cumhûruna göre i'râb özelliğine sahip olup olmaması bakımından isimleri, mu'reb ve mebnî olmak üzere iki kısma ayrılmaktadır. Mu'reb, i'râb özelliğine sahip olup cümledeki konumuna göre sonu değişebilen isimlerin ortak adıyken, mebnî, i'râb özelliğine sahip olmayan ve durum ne olursa olsun sonu asla değişmeyen isimlere denilmektedir. Dolayısıyla cumhûra göre isim ya mu'reb veya mebnî olup üçüncü bir durum söz konusu değildir.7 Ancak bir kısım dilcilere göre bazı isimler ne mu' reb ne de mebnîdir. Tartışma konusu olan isimler aşağıdaki başlıklarda yer verilmiştir.

\section{1. İsimlerin Cümle İçinde Kullanılmadan Önceki Durumları}

ثلاثة ,اثنانِ رواحدُ gibi cümle içinde kullanılmadan sadece sayı sayma

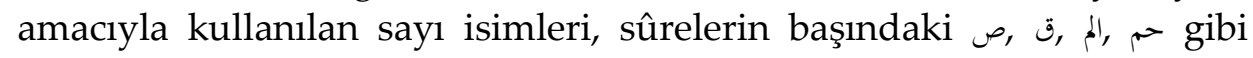
ifadeler, hece harflerinin adları olan ثاء تاء رباء رالف ve vibi isimler ve cümlede kullanılmadan önce بكر , عمرو رزيد ve gibi kelimelerin mu'reb olup olmaması hakkında dilciler ihtilaf etmişlerdir.

Bazı dilciler, ${ }^{9}$ söz konusu kelimeler cümle içinde kullanılınca i'râb aldıklarından bunları mu'reb kategorisinde saymışlardır. Dolayısıyla bu

5 İbn Cinnî, el-Hasâis, 2/358.

6 Süyûtî, el-Eşbâh ve'n-nezâir fi'n-nahv, 2/368.

7 'Ukberî, el-Lubâb fì 'İleli'l-i'râbi ve'l-binâ', 1/67; İbn Hişâm, Evdahu'l-mesâlik, 1/54; Murâdî, Tavdîhu'l-mesâlik ve'l-makâsid, 1/297.

8 İbnü'ş-Şecerî, el-Emâlî, 2/368; İbn Cinnî, el-Hasâis 2/358; Ebû Hayyân el-Endelüsî, İrtişâfü'd-darab min lisâni'l- 'Arab, 2/870; Süyûtî, el-Eşbâh ve'n-nezâir fi'n-nahv, 2/368.

$9 \mathrm{Bu}$ görüşü savunanlar arsında ismi öne çıan Zemahşerî'dir. Kaynaklarda onun dışında herhangi bir dilcinin adı zikredilmemiş ve sadece بعض النحويين ifadesiyle yetinilmiştir. Bk. Ebû 'Abdillâh Cemâluddîn Muhammed b. 'Abdillâh b. Mâlik et-Tâî İbn Mâlik, Şerhu Teshîli'l-Fevâid, thk. Muhammed Bedevî el-Mahtûn (Kahire: Mektebetu Hecer, 1990), 1/38-39; Muhammed b. Yûsuf b. Alî b. Yûsuf b. Hayyân Ebû Hayyân el-Endelüsî, et-Tezyîl ve't-tekmîl fì şerhi Kitâbi't-Teshîl, thk. Hasan Hindâvî (Dimaşk: Dâru'l-Kalem, ts.), 1/135. 
isimler, lafzen olmasa da hükmen mu'râbdirlar. Zira bunların mebnî olmasını gerektirecek herhangi bir sebep bulunmamaktadır. Nitekim Zemahşerî (öl. 538/1144), م' kelimesini tefsir ederken bunların mu'reb olduklarına dair şöyle bir açıklama yapmaktadır: "Şayet 'Bunlar (sûrelerin başındaki hece harflerinden oluşan ifadeler) ne tür isimlerdir, mebnî mi mu'râb mı?' dersen, şöyle derim: Bunlar mu'râb isimlerdir, sonlarının sakin olması ise olması gibidir. Zira bunlar i'râbı gerektiren herhangi bir âmilin etkisinde olmadıkları için sonları sakindir. Bu isimlerin son harflerinin sakin olması mebnî olduklarını göstermez, aksine bu bir tür vakıftır. Bunun delili şudur: Eğer bunlar mebnî olsalard1 o zaman هؤلاءٍ أَيْنَ , كَيْفَ kelimelerinde olduğu gibi, belli bir hareke üzere mebnî olurlardı; ن(nûn), ق (kâf), صلان (sâd) örneklerinde olduğu gibi iki sakin harf bir arada olacak şekilde telaffuz edilmezdi."10 Ancak bu kelimeler cümle içinde kullanılıp başlarında bir âmil gelirse, o zaman bunların son harfleri de i'râba tâbi olur. Bu

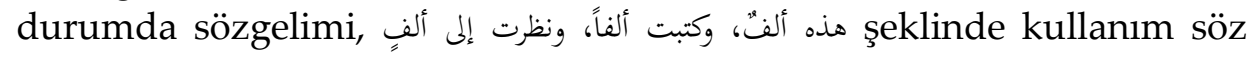
konusu olur. Aynı şekilde sadece kendisi ifade edilmek istenen ve cümle içinde kullanılmayan her mu' râb isim, harekesine etki edecek bir âmilin müdahil olmasından önce, son harfi harekesiz kılınıp üzerinde durularak

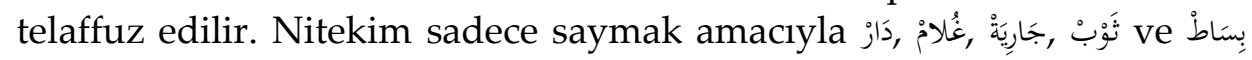
gibi kelimeler i’râb özelliğinden arındırılmakta ve son harfleri harekesiz telaffuz edilmektedir. Aynı kelimeler cümle içinde kullanıldıklarında ise i'râb kurallarına göre son harfleri hareke almaktadır. ${ }^{11}$

İbnu'l-Hâcib (öl. 646/1249), İ̉bn Mâlik (öl. 672/1274), Murâd (öl. 749/13499, Şâtıbî (öl. 790/1388) ve Üşmûnî (öl. 918/1513) gibi birçok dilciye göre ise cümlede kullanılmadan önce tüm isimler mebnîdir. ${ }^{12}$ Ancak mebnî olmalarının nedeni hususunda farklı görüşler ileri sürülmüştür.

10 Ebu'l-Kâsım Mahmûd b. Ömer b. Muhammed ez-Zemahşerî, el-Keşşâf 'an hakâikı ğavâmidi't-tenzîl ve 'uyûni'l-ekâvîl fî̀ vucûhi't-te'vîl (Beyrut: Dâru'l-Kitâbi'l-'Arabî, 1407), $1 / 21$.

11 Zemahşerî, el-Keşşâf, 1/20.

12 Murâdî, Tavdîhu'l-mesâlik ve'l-makâsid bi şerhi Elfiyyeti İbni Mâlik, 1/301; Ebû İshâk İbrâhîm b. Mûsâ b. Muhammed eş-Şâtıbî, el-Makâsidu'ş-şâfiye fì şerhi'l-Hulâsati'l-Kâfiye, thk. Muhammed İbrâhîm el-Bennâ (Mekke: Ma'hedu'l-Buhûsi'l-'Illmiyye ve İhyâu'tTurâsi'l-İslâmî, 2007), 1/87; Ebu'l-Hasan Nuruddîn 'Alî b. Muhammed b. 'Îsâ elÜşmûnî, Şerhu'l- Üşmûn̂̀ 'alâ Elfiyyeti İbn Mâlik (Beyrut: Dâru'l-Kutubi'l-'İlmiyye, 1998), $1 / 44$. 
428 I M. TAŞ / Arap Dilinde İsmin İkili Taksiminde Vâsıta Olgusu

İbnu'l-Hâcib'e göre terkîb içinde kullanılmamaları mebnî olmalarına sebep olmuştur. Zira i' râbın amacı terkîb sonucu meydana gelen manaları (faillik, mefûlluk, mübtedalık, haberlik) açıklamaktır. Dolayısıyla terkib içinde kullanılmayan isimler i'râba ihtiyaç duymamakta ve mebnî sayılmaktadır. ${ }^{13}$ İbn Mâlik'e (öl. 672/1274) göre ise söz konusu isimler mühmellik (âmillik ve ma'mûllük yönünden herhangi bir işlevi olmamaları) yönüyle harfe benzemeleri nedeniyle mebnî olmuşlardır. Dolayısıyla Kur'ân-1 Kerîm'in bazı sûrelerinin başında bulunan الر حم الم gibi ifadeler ile terkîbde kullanılmayan isimler, amel etme ve kendisinde

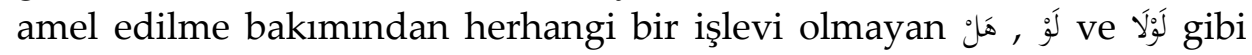
harflere benzemekte ve onlar gibi mebnî olmaktadirlar. ${ }^{14}$

İbn Usfûr (öl. 669/1270), Ebû Hayyân (öl. 745/1344) ve Süyûtî gibi dilciler, cümle içinde kullanılmayan isimlerin ne mu'reb ne de mebnî olduğunu ifade etmişlerdir. ${ }^{15}$ Zira söz konusu isimlerin i' râb veya binâsını gerektirecek herhangi bir durum söz konusu değildir. Nitekim Süyûtî

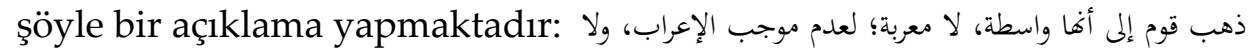
Bir kısım dilciye göre onlar (terkîbde kullanılmayan مبنية؛ لعدم مناسبة مبني الأصل isimler) vâsıtadır (mu'reb ile mebnî arsında bir yerdedir). Bu isimler mu'reb değildir. Zira onların i'râbını gerektirecek bir durum bulunmamaktadır. Mebnîyyü'l-asla benzemedikleri için mebnî de değillerdir."16

Kanaatimizce söz konusu isimleri mu'reb olarak kabul etmek daha doğru bir yaklaşımdır. Zira bir kelimenin mu' reb olması bilfiil i'râba konu olmasını gerektirmez. Nitekim dilciler arasında şöyle bir ifade

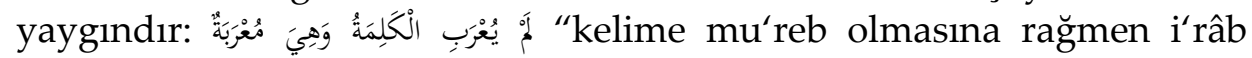
almamıştır"17

13 Ebû Amr Cemâlüddîn Osmân b. Ömer İbnu'l-Hâcib, Şerhu'l-vâfiye nazmu'l-Kâfiye, thk. Mûsâ Bennâî Alevân el-Alîlî (Necef: Matbaatu'l- Ââb, 1400), 272.

14 İbn Mâlik, Şerhu Teshîli'l-Fevâid, 1/38.

15 Ebü'l-Hasen Alî b. Mü'min b. Muhammed b. Alî el-Hadramî el-İşbîlî, Şerhu'l-cümel thk. Fevvâz eş- Şa'âr (Beyrut: Dâru'l-Kutubi'l-'İlmiyye, 1419/1998), 1/32; Ebû Hayyân el-Endelüsî, et-Tezyîl ve't-tekmîl fî şerhi Kitâbi't-Teshîl, 1/135;

16 Süyûtî, el-Eşbâh ve'n-nazâir fi'n-nahv, 2/368.

17 Nûruddîn 'Abdurrahmân b. Nizâmiddîn Ahmed b. Muhammed el-Câmi Câmî, elFevâidu'd-diyâiyye (Asitâne: Matbaatu'l-Hâc Muharrem Efendi, 1281), 16;Ebu'l-'İrfân Muhammed b. 'Alî es-Sabbân, Hâşiyetu's-Sabbân 'alâ Şerhi'l-Üşmûnî (Beyrut: Dâru'lKutubi'l-'İlmiyye, 1997), 1/85. 


\subsection{Müfred-Ma'rife ve Nekra-i Maksûde Olan Münâdâ}

Gramerde muzâf veya şibh-i muzâf olmayan münâdâ isimler, müfred münâda olarak kabul edilmektedir. Dolayısıyla münâdâ olan isim tesniye ya da cemi de olsa müfred olarak adlandırılmaktadır. Müfred münâdâ nekire ve ma'rife olmak üzere iki kısma ayrılmaktadır. Müfred nekire de maksûde (kendisiyle belli bir kişinin kastedildiği) ve gayr-1 maksûde (kendisiyle belli bir kişinin kastedilmediği) şeklinde iki kısma ayrılır. Münâdâ isimler muzâf, şibh-i muzâf ve nekir-i gayr-1 maksûde şeklinde gelirlerse mu'reb oldukları hususunda dilciler görüş birliği yapmışlardır. ${ }^{18}$ Ancak müfred-ma' rife veya nekire-i maksûde biçiminde geldiklerinde mu'reb olup olmamaları hususu tartışma konusu olmuştur. Bazı dilciler bu tür münâdâları mebnî olark kabul ederken, ${ }^{19}$ Kûfe dil ekolünün önemli temsilcilerinden olan Kisâî (öl. 189/805) onları mu'reb isimler arasında saymıştır. ${ }^{20}$ Diğer bir kısım dilciler ise bunları vâsıta (ne mu'reb ne de mebnî) kategorisine almıştır. ${ }^{21}$

Dilcilerin çoğunluğuna göre müfred-ma' rife ve nekire-i maksûde olan münâdâ isimler mebnîdir. ${ }^{22}$ Onlara göre bu tür münâdâlar şayet mu'rab olsaydı hangi alametle merfû olacaksa o alamet üzerine mebnî

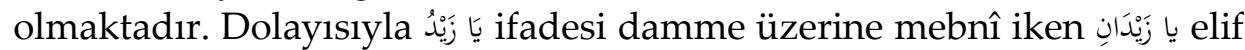
üzerine, يا زَيْدُونَ ise vâv üzerine mebnîdir. Bu durumda her üç örnekteki

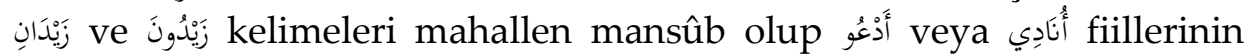
mef' ûlü konumundadırlar. ${ }^{23}$

18 Ebû Bişr Sîbeveyhi Amr b. Osmân b. Kanber el-Hârisî, el-Kitâb thk. Abdüsselâm muhammed Hârûn (Kahire: Mektebetü'l-Hâncî, 1408/1988), 2/182; Ebü'l-Kâsım Mahmûd b. Ömer b. Muhammed el-Hârizmî ez-Zemahşerî, el-Mufassal fì sinâ'ati'l-i'râb thk. 'Ali Ebû Malahham (Beyrut: Mektebetu'l-Hilâl, 1993), 60.

19 Sîbeveyhi, el-Kitâb, 2/183; Ebü'l-Abbâs Muhammed b. Yezîd b. Abdilekber b. Umeyr el-Müberred, el-Muktedab thk. Muhammed Abdülhalık 'Azîme (Beyrut: 'Âlemü'lKütüb, ts.), 4/204; İbn Serrâc, el-Usûl fi'n-Nahv, 1/146; Ebû İshâk eş-Şâtıbî, el-Makâsidu'şşâfiye fì şerhi'l-Hulâsati'l-Kâfiye, 5/254.

20 Ebû İshâk eş-Şâtıbî, el-Makâsidu'ş-şâfiye fì şerhi'l-Hulâsati'l-Kâfiye, 5/257.

21 İbn Ya'îş, Şerhu'l-Mufassal, 1/321; Süyûtî, el-Eşbâh ve'n-nazâir fi'n-nahv, 2/368.

22 Bu görüş cumhura aittir. Bk. Sîbeveyhi, el-Kitâb, 1/183; Müberred, el-Muktedab, 4/204; Ebû Bekr Muhammed b. es-Serî b. Serrâc İbn Serrâc, el-Usûl fi'n-Nahv (Beytut: Müiessesetu'r-Risâle, ts.), 1/333.

23 Meliku'l-Müeyyed 'İmâdüddîn İsmâîl b. 'Alî b. Mahmûd el-Eyyûbî Ebu'l-Fidâ', elKennâş̧ fì fenneyi'n-nahvi ve's-sarf, thk. Riyâd b. Hasan el-Havâm (Beyrut: el-Mektebtu'l'Asriyye, 2000), 1/161-162. 
Kisâî'ye göre sözü edilen her iki münâdâ da mu'rebdir. Zira mebnî olmalarını gerektirecek herhangi bir sebep bulunmamaktadır. Dolayısıyla harekesidir. ${ }^{24} \mathrm{Bu}$ görüş aynı zamanda Kûfe dil ekolünün de görüşüdür. Nitekim el-Enbârî (öl. 577/1181) el-İnsâf adlı eserinde şöyle bir açıklama yapmaktadır: ذهب الكوفيون إلى أن الاسم المنادى المعرف المفرد معرب مرفوع بغير تنوين "Kûfelilere göre müfred-ma'rife münâdâ mu'reb olup tenvin almaksızın merfû konumundadır." 25

İbn Yaîş ve Süyûtî'nin bazı dilcilerden aktardıklarına göre müfred-ma'rife ve nekire-i maksûde olan münâdalar ne mebnî ne de mu'rebdır. İbn Yaîş bu görüşe yer verirken şöyle demektedir: وقد ذهب قومُ إلى “Bir grup dilciye göre o, (müfred-ma’rife münâdâ) mu’reb ile mebnî arasındadır." 26 Yine Süyûtî de söz konusu dilcilerin görüşlerine işaret etmekte ve şöyle bir ifadeye yer vermektedir: ذهب قوم إلى أنه واسطة بين "Bir kısım dilciye göre o, mu'reb ile mebnî arasında bir konumdadır." 27

Müfred-ma' rife ve nekire-i maksûde olan münâdâ isimlerin mebnî olduklarına dair cumhûrun görüşü daha isabetli görünmektedir. Zira Kisâî, onları herhangi bir âmilin etkisi olmaksızın mu'reb saymaktadır. ${ }^{28}$ Hâlbuki mu' reb olarak kabul edildiklerinde onları merfû yapan bir âmilin olması gerekmektedir. Çünkü Arap gramerinde nasb amelini yapan bir amil olmadan mansûb bir kelime, cer eden bir âmil olmadan mecrûr bir isim söz konusu olamayacağı gibi ref' eden bir âmil olmadan merfû bir kelime de bulunmamaktadır. Dolayısıyla Kisâî'nin görüşü mesnetsiz bir iddia olarak görünmektedir. ${ }^{29}$ Yine söz konusu münâdâları vâsıta (ne mu'reb ne de mebnî) olarak kabul eden dilcilerin iddialarını ispatlayacak

24 Necmü'l-Eimme Radıyyüddîn Muhammed b. el-Hasen el-Esterâbâdî, Şerhu'r-Radî 'ale'l-Kâfiye, thk. Hasan b. Muhammed b. İbrâhîm - Yahyâ Beşîr Mustafâ (Riyad: Camiatu'l-İmam Muhammed b. Suud el-İslamiyye, 1417), 1/410-411.

25 Ebu'l-Berekât Abdurrahmân b. Muhammed el-Enbârî, el-İnsâf fî̀ mesâili'l-hilâf beyne'nnahviyyîn (el-Mektebetu'l-'Asriyye, 2003), 1/264.

26 Ebu'l-Bekâ Muvaffakuddîn Yaîş b. Alî b. Yaîş İbn Ya'îş, Şerhu'l-Mufassal (Beyrut: Dâru'1-Kutubi'l-'Illmiyye, 2001), 1/321.

27 Süyûtî, el-Eşbâh ve'n-nazâir fi'n-nahv, 2/368.

28 Ebû İshâk eş-Şâtıbî, el-Makâsidu'ş-şâfiye fì şerhi'l-Hulâsati'l-Kâfiye, 5/258.

29 Esterâbâdî, Şerhu'r-Radî 'ale'l-Kâfiye, 1/410-411. 
güçlü delillerinin bulunmaması konuyla ilgili cumhûrun görüşünün daha doğru olduğunu ortaya koymaktadır.

\subsection{Mütekellim Yâ'sına Muzâf olan İsimler}

Dilcilerin cumhûruna göre mütekellim yâ'sına muzâf olan isimler ref', nasb ve cer olmak üzere her üç durumda da mu'rebtir. ${ }^{30}$ Zira mebnî olmalarını gerektirecek herhangi bir sebep bulunmamaktadır. Ayrıca bu isimlerdeki izâfe, mu'reb olmalarını gerektirmektedir. Zira izâfe, ismin özelliklerindendir. İsimlerde asıl olan mu'reb olmalarıdır. ${ }^{31}$ Ancak bu isimlerin i'râbı lafzî değil, takdîrîdir. Dolayısıyla هذا غلامي ifadesindeki رلامي kelimesi takdîren merfû, رأيت غلامي şeklindeki cümlede takdîren mansûb, 'مررت بغلامي de ise takdîren mecrûrdur. ${ }^{32}$ İbn Mâlik başta olmak birçok dilciye göre mütekellim yâ'sına muzâf olan isimlerin i'râbı ref' ve nasb durumlarında takdîrî, cer konumda ise lafzîdir. ${ }^{33}$

İbnu'ş-Şecerî, Mutarrizî (öl. 610/1213) ve İbnu'l-Haşşâb (öl. 567/1172) gibi dilcilere göre mütekellim zamir yâ'sına muzâf olan isimler mebnîdir. ${ }^{34}$ Zira Arap dilinde muzâf olan isimlerin sonları muzâfün ileyhten dolayı herhangi bir hareke değişimine uğramamaktadır. Hâlbuki mütekellim yâ'sına muzâf olan isimlerin son harfi, yâ zamirinden dolayı kesralı olmakta ve bu sebeple benzerlerinden ayrılmaktadır. Bir isim benzerlerinden ayrilınca harflere benzemekte ve mebnî olmaktadır. Bu bağlamda mütekellim yâ'sına muzâf olan isimlerin sonundaki kesra

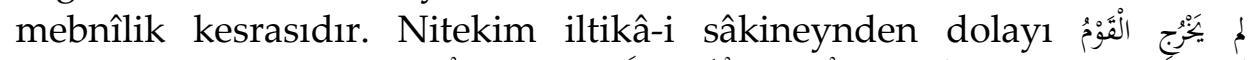

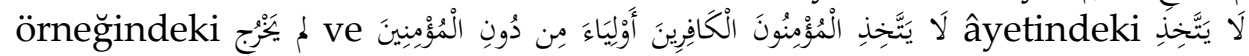
fiillerin sonlarındaki kesra da mebnîlik kesrasıdır. Zira herhangi bir âmilin etkisiyle gerçekleşmeyen harekeler i'râb değil, binâ harekeleridir. ${ }^{35}$

Bir grup gramerciye göre mütekellim yâ'sına muzâf olan isimler vâsıta (ne mu' reb ne de mebnîdir) konumundadırlar. Nitekim 'Ukberî bu

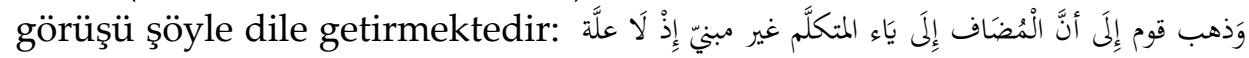

30 Ebû Hayyân el-Endelüsî, İrtişâfü'd-darab min lisâni'l- 'Arab, 4/1847; Üşmûnî, Şerhu'lÜşmûnî 'alâ Elfiyyeti İbn Mâlik, 2/197; Murâdî, Tavdîhu'l-mesâlik ve'l-makâsid, 2/834.

31 Mâlik İbnu'n-nâzım, Şerhu ibni'n-nâzım 'alâ Elfiyyeti İbni Mâlik, 294.

32 Ebû Hayyân el-Endelüsî, İrtişâfü'd-darab min lisâni'l- 'Arab, 4/1847; Üşmûnî, Şerhu'lÜşmûnî 'alâ Elfiyyeti İbn Mâlik, 2/197; Murâdî, Tavdîhu'l-mesâlik ve'l-makâsid, 2/834; Sabbân, Hâşiyetu's-Sabbân, 2/427.

33 İbn Mâlik, Şerhu Teshîli'l-Fevâid, 3/279.

34 İbn Mâlik, Şerhu Teshîli'l-Fevâid, 3/279.

35 İbnü'ş-Şecerî, el-Emâlî, $1 / 2$. 
432 | M. TAŞ / Arap Dilinde İsmin İkili Taksiminde Vâsıta Olgusu

"Bir gruba göre mütekellim yâ'sına muzâf olan isimler mebnî değildir. Zira mebnî oluşunu gerektirecek herhangi bir illet bulunmamaktadır. Söz konusu isimler mu'reb de değildir. Çünkü bu isimlerin sonundaki harfler sahih (illet harfi olmayan) olmasına rağmen i'râb açık gelememektedir. Bu gruptaki dilciler mütekellim yâ'sına muzâf olan isimleri خصِي (hadım, iğdiş) olarak adlandırmaktadır." 36 Ancak 'Ukberî, bu isimlendirmenin yanlış olduğunu ifade etmektedir. Zira iğdiş edilmiş hayvanlar müzekker sayılmaktadır. Dolayısıyla bu isimlendirme yerine نُنْنَى مُشْكَ (erkeklik ve dişilik organına birlikte sahip olan veya bu organlardan hiçbirini taşımayan) tabirinin kullanılmasının daha uygun olacağını dile getirmektedir. ${ }^{37}$

Konuyla ilgili serdedilen görüşler arasında İbn Mâlik'in görüşü daha isabetli görünmektedir. Dolayısıyla mütekellim yâ'sına muzâf olan isimler mu'reb olup ref' ve nasb durumlarında irabları takdîrî, cer konumda ise lafzîdir. Zira izâfe, ismin özelliklerindedir. İsimlerde asıl olan mu'reb olmasıdır. Ancak ref' ve nasb konumlarında açık i'râbın gelmesi mümkün değildir. Çünkü mütekellim yâ'sından dolayı bu isimlerin son harfi kesralı gelmek zorundadır. Ancak cer konumunda zaten açık bir kesra bulunmaktadır. Dolayısıyla bu kesrayı i'râb değil, binâ harekesi olarak değerlendirmek gereksiz bir zorlamadan ibaret olacaktır. ${ }^{38}$

\subsection{Belirli Bir Günün Seherinin Kastedildiği سَحَر Kelimesi}

سَخر kelimesi bazen nekire olup kendisinden herhangi bir seher vakti kastedilmektedir. Bu durumda mu'reb olması hususunda dilciler arasında görüş birliği vardır. Nitekim نَ seheri kastedilmediğinden tenvin alarak mu'reb olmuştur. Bazı durumlarda ise سَحَر kelimesinden belli bir günün seheri kastedilmektedir. Böyle durumlarda söz konusu kelimenin mu'reb olup olmaması hususu gramerciler arasında tartışma konusu olmuştur. ${ }^{39}$

36 ‘Ukberî, el-Lubâb fì 'İleli'l-i'râbi ve'l-binâ', 1/67.

37 ‘Ukberî, el-Lubâb, 1/67.

38 İbn Mâlik, Şerhu Tashîli'l-Fevâid, 3/279.

39 Ebû Muhammed Bahâuddîn 'Abdullah b. 'Abdirrahmân b. Akîl İbn 'Akîl, Şerhu İbn 'Akîl 'alâ Elfiyyeti İbn Mâlik, thk. Muhammed Muhyiddin Abdulhamid (Kahire: Dâru'tTurâs, 1980), 3/355. 
Dilcilerin cumhûruna göre سَحَر kelimesiyle belli bir günün seheri kastedilince mu'reb olup gayr-1 munsarıftır. ${ }^{40}$ Onlara göre bu anlamdaki سَحَر kelimesi السحر dönüşmüştür. Ayrıca kastedilen günün seherinin özel adı konumundadır. Dolayısıyla wَ kelimesinin munsarıf olmasını engelleyen adl ve alemiyyet vardır. ${ }^{41}$ Ancak başta Şelevbîn (öl. 645/1247) olmak üzere bazı dilciler, bu durumdaki سَخَ kelimesinin gayr-1 munsarıf

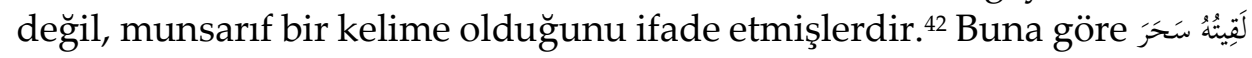
“onunla o günün seherinde karşılaştım” cümlesindeki wَ kelimesinin tenvin alamaması iki sebebe bağlanmıştır. Süheylî, izâfe kastına bağlamış

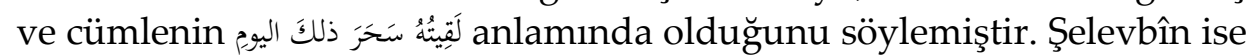

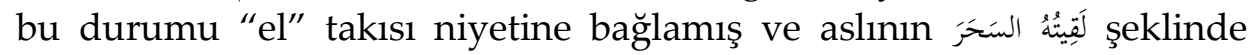
olduğunu ifade etmiştir. ${ }^{43}$

İbnu't-Tarâve (öl. 528/1134) ve Nâsır el-Mutarrizî (öl. 610/1213) gibi bazı dilciler, söz konusu kelimenin mu'reb değil, fetha üzerine mebnî olduğunu dile getirmişlerdir. Ancak mebnî oluşunun sebebi hakkında farklı iki görüş ileri sürülmüştür. Bazılarına göre, ta'rîf harfi olan el takısının anlamını içerdiği için fetha üzerine mebnî olmuştur. Nitekim aynı sebepten dolayı أَمِ kelimesi kesra üzerine mebnî olmuştur. Diğger bir kısım dilciye göre ise mebnî oluşunun sebebi, harfin anlamını

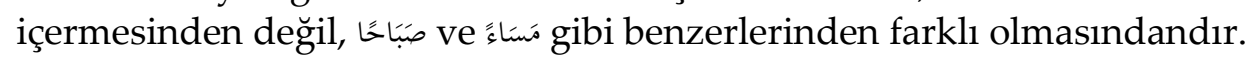
Zira bir isim benzerlerinden farklı olunca harfe benzemiş olmakta ve bu sebeple mebnî konumuna gelmektedir. ${ }^{44}$

Rummânî'ye göre kendisiyle belirli bir günün seheri kastedilen سَخَر kelimesi ne mebnî ne de mu'rebtir. Dolayısıyla bu kelime vâsita konumundadır. Zira bu kelime şayet mu'reb olsaydı son harfi aynı harekeye bağlı kalmazdı. Çünkü mu'reb, cümledeki konumuna göre

40 Sîbeveyhi, el-Kitâb, 1/225; Müberred, el-Muktedab, 3/378; İbn Serrâc, el-Usûl fi'n-Nahv, $1 / 192$.

${ }^{41}$ Ebû Muhammed Bahâuddîn 'Abdullah b. 'Abdirrahmân b. Akîl İbn 'Akîl, Şerhu İbn 'Akîl 'alâ Elfiyyeti İbn Mâlik, thk. Muhammed Muhyiddin Abdulhamid (Kahire: Dâru'tTurâs, 1980), 3/355.

42 Ebû Hayyân el-Endelüsî, İrtişâfü'd-darab min lisâni'l- 'Arab, 2/870.

43 Ebu'l-Kâsım Abdurrahmân b. Abdillâh b. Ahmed es-Süheylî, Netâicu'l-fiker fi'n-nahv (Beyrut: Dâru'l-Kutubi'l-i̇lmiyye, 1992), 226.

44 Bk. Celâluddîn Abdurrahmân b. Ebî Bekr es-Süyûtî, Hemu'l-hevâmi' fì şerhi Cem'i'lCevâmi', thk. 'Abdulhamîd el-Hindâvî, (Mısır: el-Mektebetü't-Tevfîkiyye, ts.), 1/106; Murâdî, Tavdîhu'l-mesâlik ve'l-makâsid bi şerhi Elfiyyeti İbni Mâlik, 3/1218. 
sonu değisşen isimdir. Sözü edilen kelime mebnî de değildir. Zira onun mebnîliğine sebep olacak herhangi bir illet söz konusu değildir. ${ }^{45}$

سَحَر kelimesiyle ilgili serdedilen görüşler incelendiğinde, bu kelimeyi mu'reb-munsarıf olarak kabul eden Şelevbîn ve Süheylî’nin görüşü daha makul bir yaklaşım gibi görünmektedir. Zira mebnî olsaydı i'râb ve binâ harekeleri birbiriyle karışmasın diye fetha üzerine değil,

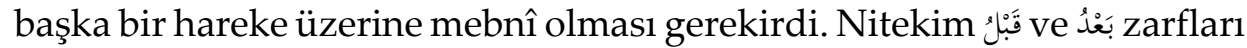
da mebnî olduklarında söz konusu endişeden dolayı damme harekesini almaktadırlar. Bu kelimeyi mu'reb-gayr-1 munsarıf kabul edenlerin görüşü de problemli görünmektedir. Zira onlara göre سَخَ kelimesini gayr1 munsarıf haline getiren illetlerden biri alemiyyetdir. Ancak bu kelimenin السَّحَر kelimesinden dönüştüğünü açıkça ifade etmeleri, سَحَر kelimesinin ma'rife olmasının nedeninin alemiyyet değil, gizli ta'rîf edatı olan "el" takısı olduğunu göstermektedir. Hâlbuki isimleri gayr-1 munsarıf yapan ta'rîf, alemiyyetten kaynaklanan bir ta'rîf olmalıdır.

\subsection{Zarf ve Alem Olan أَمْسِ Kelimesi}

Kendisiyle belirli bir gün kastedilen أَمْس (dün) kelimesi bazen isim, bazen zarf (mef' ûlün fîh) olarak kullanılmaktadır. Bu kelime isim olarak

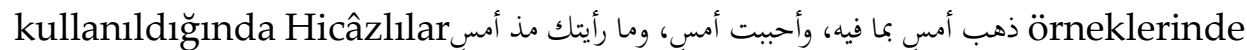
olduğu gibi ref', nasb ve cer olmak üzere her üç konumda da kesra üzere mebnî biçiminde kullanmaktadırlar. Temîm lehçesinde ise iki şekilde kullanılmıştır. Onların cumhûru, bu kelimenin ref' konumunda gayr-1 munsarıf; nasb ve cer konumlarında ise kesra üzere mebnî olduğunu söylemektedirler. Dolayısıyla onlar, cümle içinde isim olan أمس وعelimesini, şeklinde i’râb alacağını ifade etmektedir.

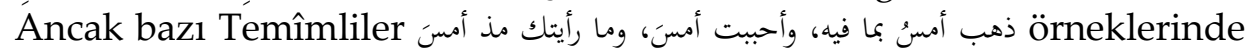
olduğu üzere söz konusu kelimeyi her üç konumda da gayr-1 munsarıf olarak kullanmaktadır. ${ }^{46}$

أَمْسِ kelimesi zarf olarak kullanıldı̆̆ında ise bütün Arap lehçelerinde her üç konumda da sonu kesralı olarak okunmuştur. ${ }^{47}$ Ancak

45 Süyûtî, el-Eşbâh ve'n-nazâir fi'n-nahv, 2/372.

46 Ebû Muhammed Cemâluddîn 'Abdullâh b. Yûsuf b. 'Abdillâh b. Hişâm el-Ensârî, Şerhu katri'n-nedâ ve belli's-sadâ, thk. Muhammed Muhyiddîn 'Abdulhamid (Kahire: y.y., 1383), 15-19.

47 Ebu'l-Velîd Zeynuddîn Hâlid b. 'Abdillâh b. Ebî Bekr el-Ezherî, Şerhu't-tasrîh 'ala'ttevdîh (Beyrut: Dâru'l-Kutubi'l-'İlmiyye, 2000), 2/347-349. 
dilciler, zarf olan أَهْس kelimesinin sonunun kesralı olmasının sebebi hakkında görüş ayrıllı̆̆ına düşmüşlerdir. ${ }^{48}$

Dilcilerin çoğunluğuna göre zarf olarak kullanılan أَمْسِ kelimesinin sonundaki kesra, binâ harekesi olup kelime mebnîdir. Zira أَمْنس kelimesi, الأمس 'den madûldür (dönüşmüştür). Dolayısıyla bu kelime ta' rîf harfi olan "el" takısının anlamını içermektedir. Bütün harfler mebnî oldukları gibi onların anlamını içeren isimler de mebnîdir. ${ }^{49}$

Halîl b. Ahmed, bu durumdaki أَمْس kelimesinin sonundaki لََِيُُهُ أَمْسِ

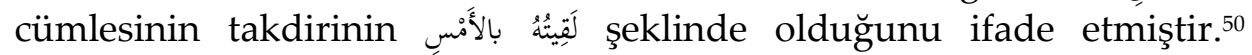
Dolayısıyla bu durumda kendisiyle belirli bir gün kastedilen ve zarf konumunda olan أَمْس kelimesi mebnî değil, mu'rebtir.

Bir grup dilciye göre söz konusu أَمْس kelimesi vâsıta konumunda olup ne mu'reb ne de mebnîdir. Onlara göre bu kelime aslinda أَمْنى يُمْسبي fiilinin emir sîgası olup sonundaki kesra mahkî harekesidir. Daha sonra bu kelime içinde bulunulan günün öncesindeki güne (dün) isim olmuştur. ${ }^{51}$

Kanaatimizce أَمْسِ kelimesinin sonundaki kesrayı i'râb harekesi kabul etmek veya bu kelimenin vâsıta konumunda olduğunu ileri sürmek zorlama bir yaklaşımdır. Dolayısıyla dilcilerin çoğunluğunun da ifade ettiği gibi bu kelimeyi mebnî olarak kabul etmek daha isabetli bir görüştür.

\subsection{Sonunda İtbâ Harekesi Bulunan İsimler}

Arap dilinde isimlerin sonundaki harfin kendisinden sonra gelen harfin harekesine uyması sıkça rastlanan bir durumdur. Bu harekeye itbâ

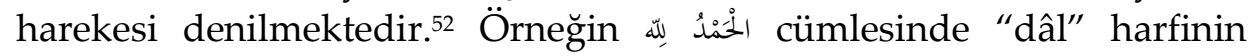

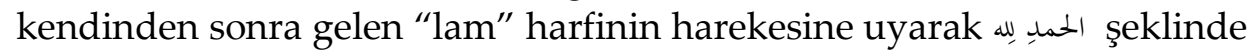

48 Bk. Ebû Hayyân el-Endelüsî, İrtişâfü'd-darab min lisâni'l- 'Arab, 3/1427; Ebü'l-Berekât Kemâlüddîn Abdurrahmân b. Muhammed b. Ubeydillâh el-Enbârî, Esrâru'l-arabiyye (b.y.: Dâru'l-Erkam, 1999), 52; Süyûtî, Hemu'l-hevâmi' fì şerhi Cem'i'l-Cevâmi', 2/188.

49 Enbârî, Esrâru'l-arabiyye, 52.

50 Süyûtî, Hemu'l-hevâmi' fì şerhi Cem'i'l-Cevâmi', 2/188.

51 Ebû Hayyân el-Endelüsî, İrtişâfü'd-darab min lisâni'l- 'Arab, 3/1427.

52 Ebû Muhammed Necmüddîn (Tâcüddîn) Abdullāh b. Abdilmü'min b. el-Vecîh elVâsitî, el-Kenz fi'l-kırââti'l-'aşr, thk. Halid el-Meşhedânî (Kahire: Mektebetü'sSekâfeti'd-Diniyye, 1425/2004), 1/62. 
436 | M. TAŞ / Arap Dilinde İsmin İkili Taksiminde Vâsıta Olgusu

okunmuştur. ${ }^{53}$ Gramerciler arasında itbâ harekesi bulunan isimlerin mu'reb mi, yoksa mebnî mi tartışması yapılmıştır.

Cumhûra göre sonunda itbâ harekesi bulunan isimler mu'rebtır. Ancak son harfleri itbâ harekesiyle meşgul olduğundan bunların i'râbları lafzî değil, takdîrîdir. ${ }^{54}$

Ahfeş ve İbnu's-Sâiğ gibi dilcilere göre söz konusu isimler mebnîdir. Nitekim Ahfeş Me'âni'l-Kur'ân adlı eserinde şöyle bir açılama

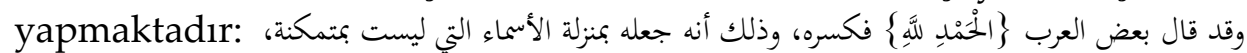

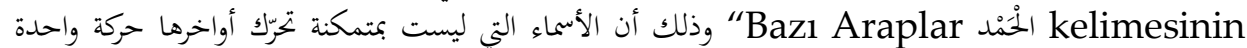

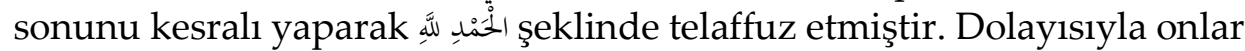
bu ismin sonunu sürekli kesralı okumuşlar ve mebnî olan isimlerin konumuna getirmişlerdir. Zira mebnî isimlerin sonu da hep aynı hareke bulunmaktadır." 55

Bir kısım dilciye göre sonunda itbâ harekesi bulunan isimler vâsıta konumunda olup ne mu'reb ne de mebnîdir. ${ }^{56}$ Zira bu isimlerin sonundaki harekenin i'râb harekesi olmadığı ortadadır. Ayrıca bu isimlerin sonu, başına gelen amillerden dolayı değişmemektedir. Yine bunların mebnî olması da düşünülemez. Çünkü mebnî olmalarını gerektirecek herhangi bir sebep bulunmamaktadır. ${ }^{57}$

Sonunda itbâ harekesi bulunan isimlerin mu'reb olduğuna dair cumhûrun görüşünün serdettikleri deliller bakımından daha güçlü olduğu kanaatindeyiz.

\subsection{Soru Edatı Olan هَْden Sonra Gelip Mahkî İrâb Alan Alem İsimler}

Hicâz lehçesinde جاء زيدُ، رأَيْت زيدًا، مررت بزيدٍ örneklerinde geçen akıllı özel isim olan زيد زئن ille ilgili soru edatını kullanarak bilgi talep eden bir

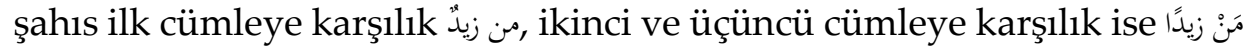

53 Ebu'l-Feth Osmân el-Mevsılî İbn Cinnî, el-Muhteseb fî tebyîni vucûhi şevâzzi'l-kırââti ve'lîdâhi 'anhâ (Kahire: Vizâretu'l-Evkâf el-Meclisu'l-A'lâ li'ş-Şuûni'l-İslâmiyye, 1999), $1 / 37$.

54 Süyûtî, Hemu'l-hevâmi' fì şerhi Cem'i'l-Cevâmi', 1/75.

55 Ebu'l-Hasen Saîd b. Mes'ade el-Ahfeş el-Evsat, Me'âni'l-Kur'ân, thk. Hudâ Mahmud Karra'â (Kahire: Mektebetu'l-Hâncî, 1411/1990), 1/9.

56 Kaynaklarda bu görüşü savunan dilcilerin isimleri dile getirilmemiş, وقيل ifadesiyle yetinilmiştir. Bk. Süyûtî, Hemu'l-hevâmi' fî şerhi Cem'i'l-Cevâmi', 1/75.

57 Süyûtî, Hemu'l-hevâ, 1/75. 
ve مَنْ زيد kelimesinin harekesini değiştirmeden mahkî i'râb ile telaffuz etmesi caiz görülmüştür. ${ }^{58} \mathrm{Bu}$ bağlamda mahkî i'râb alarak soru edatı olan مَ'den sonra gelen akıllı alemlerin mu'reb mi, mebnî mi, yoksa ne mu'reb ne de mebnî mi olduğu tartışılmıştır. Bu tartışmaya aşağıda kısaca yer verilmiştir.

Dilcilerin cumhûruna göre مَ'den sonra gelip mahkî i'râb alan isimler merfû, mansûb veya mecrûr olmaları bakımından ayrım yapılmaksızın her üç durumda da takdîren merfû olup mu'reb olmaktadır. Zira نَden sonra gelen isimler ya mübtedâ veya haber konumundadırlar. Ancak bazı dilciler mansûb veya mecrûr şeklinde gelenlerin i'râbı takdîrî, merfû gelenlerin ise lafzî olarak kabul etmektedir. Zira zaten açık olan ref' alametini saymayıp başka bir ref' alametini takdir etmek anlamsız bir yaklaşımdır. Kanaatimizce bu görüş daha isabetlidir..$^{59}$

Süyûtî'nin İbn 'Usfûr'dan (öl. 669/1270) aktardığına göre نَ'den sonra gelip mahkî i' râb alan alem isimler mu' reb değil, mebnîdir. ${ }^{60}$ Ancak bu görüş zayıftır. Zira bu isimlerin mebnîliğini gerektirecek herhangi bir sebep bulunmamaktadır. Dolayısıyla gramerin genel kaidesi olan "isimlerde asıl olan mu'reb olmalarıdır" kuralı gereğince söz konusu isimleri mu'reb kabul etmek daha makuldür.

Ebû Hayyân (öl. 745/1344) ve el-Murâdî (öl. 749/1348) gibi dilcilere göre sözü edilen isimler vâsita konumunda olup ne mu'reb ne de

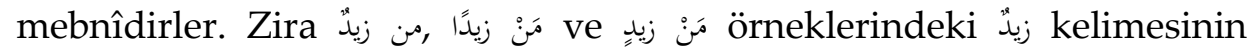
sonundaki hareke i'râb veya binâ harekesi değil, mahkî bir harekedir. ${ }^{61}$ Ancak bu isimlerin sonundaki harekenin mahkî bir hareke olması, onların mu'reb olmalarını engellememektedir. Zira bunları mu'reb kabul eden cumhûr da i'râblarının takdîrî olduğunu açıkça ifade etmişlerdir.

58 Ebû 'Alî Hasan b. Ahmed b. 'Abdilgaffâr el-Fârisî, et-Ta'lîka 'alâ Kitâbi Sîbeveyh, thk. 'Avd b. Hamd el-Kûzî (b.y.: y.y., 1410/1990), 2/111-112.

59 Süyûtî, Hemu'l-hevâmi' fì şerhi Cem'i'l-Cevâmi', 3/267.

60 Süyûtî, Hemu'l-hevâmi' fì şerhi Cem'i'l-Cevâmi', 1/75.

61 Murâdî, Tavdîhu'l-mesâlik ve'l-makâsid,3/1350; Süyûtî, Hemu'l-hevâmi' fì şerhi Cem'i'lCevâmi', 1/75. 
438 | M. TAŞ / Arap Dilinde İsmin İkili Taksiminde Vâsıta Olgusu

\section{Ma'rife ve Nekira Bağlamında Vâsıta Konumundaki İsimler}

Gramerciler, belirli bir varlığ 1 gösterip göstermeme bakımından ismi márife ve nekire olmak üzere iki kısma ayırmaktadır. Dolayısıyla başında harf-i ta'rif (ل takısı) olan, özel isimler, zamirler, işâret ve mevsûl isimleri, ma'rife bir isme muzâf olanlar ma'rife, bunların dişındakiler ise nekire sayılmaktadır. ${ }^{62}$

Dilcilerin cumhûruna göre Arap dilindeki tüm isimler ya márife veya nekiredir. ${ }^{63} \mathrm{Bu}$ bakımdan ikili taksime girmeyip vâsıta konumunda olan isimlerin varlığ 1 söz konusu değildir. ${ }^{64}$ Ancak bazı dilciler bu taksime itirazda bulunmakta ve bazı isimlerin ne ma'rife ne de nekire olduğunu vurgulamaktadır. Onlara göre "el" takısı ve tenvîn alamayan istifhâm

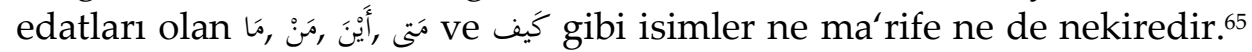
Zira bunlar nekire kapsamına girmemektedir. Çünkü nekire isimlerin ya "el" takısı alabilmesi veya "el" takısı alabilen bir kelimenin anlaminda olması gerekmektedir. Hâlbuki söz konusu istifhâm edatları "el" takısı alamadıkları gibi onu alabilen bir ismin anlamında da değillerdir. Ayrıca bu isimler ma'rife de değildir. Zira anlamlarında umum vardır. Dolayısıyla anlam bakımından márifeden çok, nekreye yakındırlar. Ancak İbn Keysân (öl. (ö. 320/932) gibi bazı dilciler soru edatı olan من vo edatlarının ma'rife isimlerin kapsamına girdiğini ifade etmiştir. Nitekim

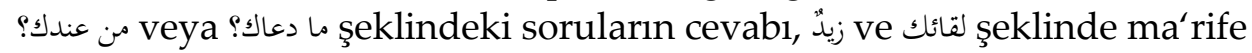
gelmektedir. من vن vo soru edatlarının cevapları ma'rife geldiğine göre bunlar da ma'rife olmalıdır. ${ }^{66}$

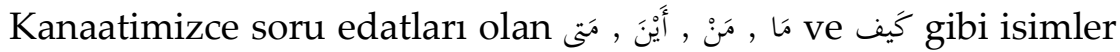

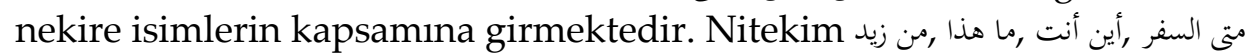

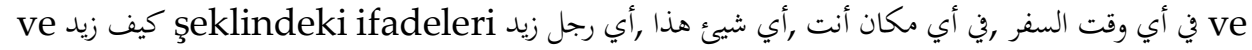
anlamindadir. Dolayısiyla bu soru edatları "el" takisı almamakla birlikte "el" takısı alabilenlerin anlamındadırlar. Bu yüzden

62 Bk. Ebû Amr Cemâlüddîn Osmân b. Ömer İbnu'l-Hâcib, el-Kâfiye fi'n-nahv, thk. Sâlih 'Abdulazîm (Kahire: Mektebetu'l-Âdâb, 2010), 1/12; İbn Mâlik, Şerhu Teshîli'l-Fevâid, 1/115; Müberred, el-Muktedab, 4/276-280.

63 Bk. Zemahşerî, el-Mufassal, 245; Murâdî, Tavdîhu'l-mesâlik ve'l-makâsid, 1/359; Sabbân, Hâşiyetu's-Sabbân, 1/158.

64 Üşmûnî, Şerhu'l- Üşmûnî 'alâ Elfiyyeti İbn Mâlik, 1/86.

65 Sabbân, Hâşiyetu's-Sabbân, 1/158; Süyûtî, Hemu'l-hevâmi' fî şerhi Cem 'i'l-Cevâmi', 1/222.

66 İbn Mâlik, Şerhu Teshîli'l-Fevâid, 1/119. 
bunlar birer nekire isimdirler. İbn Keysân'ın من vo edatlarının ma'rife

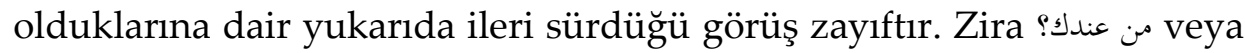
seklinde nekire isimler de gelebilmektedir. ${ }^{67} \mathrm{Bu}$ bağlamda cumhûrun "Arap dilindeki tüm isimler ya márife veya nekiredir" şeklindeki görüşü daha doğru bir görüştür.

\section{3. İsmin Zâhir ve Zamir Taksiminde Vâsıta}

Dilciler isimleri zâhir ve zamir olmak üzere iki kısma ayırmaktadır. Bu bağlamda onlara göre Arap dilindeki bütün isimler ya zâhir veya zamir olup vâsıta (ne zâhir ne de zamir) konumunda olan isimler söz konusu değildir. ${ }^{68}$ Ancak genel kanaate göre mansûb munfasıl olarak kabul edilen إياي رإياه رإياك ve türevlerinin zâhir isimlerin mi, zamirlerin mi, yoksa ne zâhir ne de zamirlerin mi kapsamına girdiği hususu dilciler arasında tartışma konusu olmuştur. ${ }^{69}$

Basrâ dil ekolünün cumhûruna göre zamir olan إي ifadesidir. Bu ifadenin sonuna bitişen yâ, kef ve hâ gibi bitişkenler harf olup zamir olan إيا'nın mütekellim, gâib ve muhâteba ait olmasının durumunu belirtmek üzere getirilmektedir. ${ }^{70}$ Bazı dilciler hem إي hem de bitişkenleri birer zamir kabul etmekte ve إيا zamirinin kendisinden sonra gelen zamirlere muzâf olduğunu dile getirmektedir. Ancak bu görüşü kabul görmemiştir. Zira zamirler izâfe edilmemektedir. ${ }^{71}$

Zeccâc'a (öl. 337/949) göre iإي ifadesi zamir değil, zâhir bir isimdir. Ona göre إيا'dan sonra gelen yâ, kef ve hâ gibi bitişkenler birer zamir olup إيا nın muzâfün ileyhisidir. Ancak birçok dilci Zeccâc'a "إيا ifadesi zâhir isim olsaydı her zaman nasb konumunda olmazdı. Zira bazı istisnalar hariç zâhir isimler belli bir i'râb çeşidine bağlı kalmamaktadır." şeklinde haklı bir eleştiri yöneltmişlerdir. ${ }^{72}$ İbn Bâbşâz'ın (öl. 469/1077) aktardığına

67 İbn Mâlik, Şerhu Teshîli'l-Fevâid, 1/119.

68 Câmi, el-Fevâidu'd-diyâiyye,150; Muhammed b. 'Abdirrahîm el-Ömerî el-Meylânî, Şerhu'l-muğnî fi'n-nahv (Dersaadet: Mektebetu's-Sanâyi', 1311), 45-46.

69 Bk. İbn Mâlik, Şerhu Teshîli'l-Fevâid, 1/144-146; İbn Ya'îş, Şerhu'l-Mufassal, 2/311-3115; Enbârî, el-İnsâf fî̀ mesâili'l-hilâf beyne'n-nahviyyîn, 2/570-275.

70 Enbârî, el-İnsâf fî̀ mesâili'l-hilâf beyne'n-nahviyyîn, 2/570.

71 Bk. Ebû Hayyân el-Endelüsî, et-Tezyîl ve't-tekmîl fî şerhi Kitâbi't-Teshîl, 2/205-215.

72 Bk. Enbârî, el-İnsâffî mesâili'l-hilâf beyne'n-nahviyyîn, 2/571-572. 
göre bazı dilciler, sadece إيا'nın, sonundaki bitişkenleriyle birlikte zâhir bir isim olduğunu ifade etmişlerdir.73

İbn Keysân ve bazı Kûfelilere göre إي ifadesi isim değil, zâid bir harf konumundadır. Zamirlere dayanak olsun ve muttasıl ile munfasıl zamirler birbirinden ayrılsın diye getirilmiştir. Dolayısıyla zamir isimler, إيا'nın sonundaki bitişkenlerdir. ${ }^{74}$ Kûfe dil ekolünün cumhûruna göre ise bitişkenleriyle birlikte zamirdir. Dolayısıyla إياك , إياه , إياي ve türevlerinin tamamı birer zamir isimdir. 75

İbn Dürüsteveyhi (öl. 347/958) ve Ahfeş'e göre ise zamir olan إيا nin sonundaki yâ, kef ve hâ gibi bitişkenlerdir. إl ifadesi ise ne zâhir ne de zamirdir. Dolayısıyla bu ifade vâsıta konumundadır. ${ }^{76}$

\section{Muttasıl ve Munfasıl Taksiminde Vâsıta}

Gramercilerin cumhuruna göre Arap dilinde zamirler muttasıl ve munfasıl olmak üzere iki kısma ayrılmaktadır. ${ }^{77}$ Muttasıl zamirler de bâriz ve müstetir şeklinde ikiye ayrılmaktadır. Müstetir zamirler, telaffuzda ya da yazıda görülmeyip fiilde var olduğu düşünülen zamirlerdir. Bunlar da vâcibu'l-istitâr ve câizu'l-istitâr olmak üzere iki

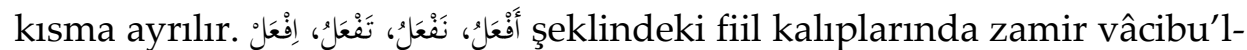

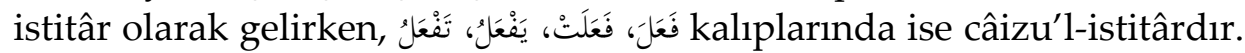
$\mathrm{Bu}$ bağlamda dilcilerin genel kanaatine göre müstetir zamirler, muttasıl zamirlerin kapsamina girmektedir. Dolayısıyla Arap dilindeki bütün zamirler ya muttasıl veya munfasıldır. Ancak bazı dilciler bu taksime itiraz etmekte ve müstetir zamirlerin vâsıta konumunda olup ne muttasıl ne de munfasıl zamirlerin kapsamına girdiğine dair bir görüş ileri sürmektedirler. ${ }^{78}$

73 Bk. Tahir b. Ahmed İbn Bâbşâz, Şerhu'l-mukaddimeti'l-muhassibe, thk. Hâlid. Abdülkerîm (b.y: el-Matbaatu'l-Asriyye, 1977), 1/153-154.

74 İbn Bâbşâz, Şerhu'l-mukaddimeti'l- muhassibe.

75 Enbârî, el-İnsâffî mesâili'l-hilâf beyne'n-nahviyyîn.

76 İbn Ya'îş, Şerhu'l-Mufassal, 2/315.

77 Bk.İbnu'l-Hâcib, el-Kâfiye fi'n-nahv, 32; Zemahşerî, el-Mufassal, 166; Murâdî, Tavdîhu'lmesâlik ve'l-makâsid, 1/359; Ezherî, Şerhu't-tasrîh 'ala't-tevdîh, 1/99; Ebû Hayyân elEndelüsî, et-Tezyîl ve't-tekmîl, 2/130.

78 Câmi, el-Fevâidu'd-diyâiyye,150; Meylânî, Şerhu'l-muğnî fi'n-nahv, 45-46. 
Dilcilerin cumhûruna göre müstetir zamirler muttasıl zamirlerin kapsamina girmektedir. ${ }^{79}$ Nitekim el-Murâdî Tavdîhu'l-mesâlik ve'lmakâsid adlı eserinde şöyle bir açıklama yapmaktadır: والضمير قسمان: متصل "Zamir iki kısma ayrılmaktadır; muttasıl ve munfasıl. Muttasıl zamirler de iki kısımdır; bâriz ve müstetir. Söz konusu taksim cumhûra aittir." 80 Ancak müstetir zamirler ifade edilirken munfasıl zamirlere ait olan lafızlarla dile getirilmektedir.

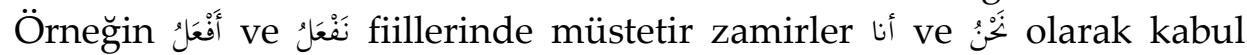
edilmektedir. Zira müstetir zamirler zihnen var olduğu kabul edilmekle birlikte kendilerine ait özel lafızlar bulunmamaktadır. Dolayısıyla bunlar ya mansûb muttasıl veya merfû munfasıl ile dile getirilmelidir. Müstetir zamirler fâil olup merfû konumunda olunca merfû munfasil olan zamirlerle dile getirilmeleri daha uygun düşmektedir. ${ }^{81}$

Bazı dilciler müstetir zamirleri muttasıl değil, munfasıl zamir olarak değerlendirmektedir..$^{82}$ Nitekim müstetir zamirler dile getirilirken munfasıl zamirlerin lafızlarıyla ifade edilmektedir. Ancak daha önce cumhûrun de ifade ettiği gibi bu durum, müstetir zamirleri ifade etme zorluğundan kaynaklanmaktadır. Zira Arap dilinde müstetir zamirlere ait özel zamirler bulunmamaktadır.

Hudarî'nin (öl. 1798/1870) bazı dilcilerden aktardığına göre müstetir zamir vâsıta konumunda olup ne muttasıl ne munfasıl zamirin kapsamına girmektedir. Zira ittisâl ve infisâl vücutta varlığı bulunan lafızlara özgü bir özelliktir. Müstetir zamirlerin böyle bir durumu söz konusu değildir. ${ }^{83}$

\section{Menkûl ve Mürtecel Taksiminde Vâsıta}

Arap gramercileri özel isimleri alem-i menkûl ve alem-i mürtecel olmak üzere iki kısma ayırmaktadır. Daha önce alemin dışında başka bir anlamda kullanılan özel isimlere alem-i menkûl, herhangi bir yerden

79 Konuyla ilgili bk. İbnu'l-Hâcib, el-Kâfiye fi'n-nahv, 33; Zemahşerî, el-Mufassal,166; Murâdî, Tavdîhu'l-mesâlik ve'l-makâsid, 1/359; Ezherî, Şerhu't-tasrîh 'ala't-tevdîh, 1/99; Ebû Hayyân el-Endelüsî, et-Tezyîl ve't-tekmîl, 2/130.

80 Murâdî, Tavdîhu'l-mesâlik ve'l-makâsid, 1/359.

81 Ezherî, Şerhu't-tasrîh 'ala't-tevdîh, 1/97.

82 Yâsîn b. Zeynuddîn, Hâşiytu Yâsîn ala't-tasrîh (Kahire: el-Matbaatu'l-Ezheriyye, 1326), $1 / 97$.

83 Muhammed b. Mustafâ b. Hasan el-Hudarî, Hâşiyetü'l-Hudarî 'alâ Şerhi İbni 'Akîl (Beyrut: Dâru'l-Fikr, 2003), 1/99. 
nakledilmeyip ilk vazından itibaren Arap dilinde alem olarak kullanılan isimlere ise alem-i mürtecel denilmektedir. ${ }^{84}$ Nitekim İbn Mâlik el-Elfiyye adlı eserinde bu durumu şöyle bir beyitle açıklamaktadır:

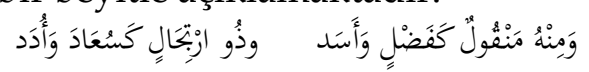

"Fadl (masdar kalıbından alıntı) ve Esed (ism-i ayn olarak değerlendirilen kavramdan alıntı) gibi bazı alemler menkûl iken, (bir kadının ismi olan) Su'âd ve (bir erkeğin ismi olan) Uded gibi bazıları da mürteceldir." ${ }^{85}$

Arap dilindeki bütün alemler ya menkûl veya mürtecel olduğuna dair görüş dilcilerin cumhûruna ait bir görüştür. ${ }^{86}$ Dolayısıyla vâsıta (ne menkûl ne de mürtecel) konumunda olan alemler söz konusu değildir. Ancak bu konuda farklı görüşler ileri süren dilciler de olmuştur. ${ }^{87}$

Zeccâc'a göre Arap dilindeki bütün alemler mürteceldir. ${ }^{88}$ Zira Ona göre alemler vazedilirken herhangi bir kavramdan alıntı yapma niyeti söz konusu değildir. Vaz' esnasında herhangi bir kavramdan nakletme kastı bulunmayan bütün isimler mürtecel sayılmaktadır. Dolayısıyla فَضْ kelimesi özel isim olarak kullanılırken kelimenin daha önceki masdar anlamı gözetilmemektedir. ${ }^{89} \mathrm{Bu}$ bakımdan bütün özel isimler murtecel olmaktadır. Ancak bu zayıf bir görüştür. Zira bazı isimlerin alem olmadan önceki anlamı düşünülerek ve tefâül amacıyla alem olarak vazedildikleri bilinen bir vakıadır. Nitekim bazı alemlerin başına özel isim haline gelmeden önceki anlamına dikkat çekmek (lemh)

84 Murâdî, Tavdîhu'l-mesâlik ve'l-makâsid, 1/393.

85 Ebû 'Abdillâh Cemâluddîn Muhammed b. 'Abdillâh b. Mâlik et-Tâi İbn Mâlik, elElfiyye, thk. Süleyman b. Abdülaziz (Riyad: Mektebetu Dâri'l-Minhâc, 1428), 80.

86 Murâdî, Tavdîhu'l-mesâlik ve'l-makâsid, 1/393; Ezherî, Şerhu't-tasrîh 'ala't-tevdîh, 1/128; Ebû Hayyân el-Endelüsî, et-Tezyîl ve't-tekmîl, 2/307.

87 Ebû Hayyân el-Endelüsî, et-Tezyîl ve't-tekmîl, 2/307; Murâdî, Tavdîhu'l-mesâlik ve'lmakâsid, 1/394; Ezherî, Şerhu't-tasrîh 'ala't-tevdîh, 1/128; Ebû İshâk eş-Şâtıbî, elMakâsidu'ş-şâfiye fî şerhi'l-Hulâsati'l-Kâfiye, 1/378.

88 Ebû Hayyân, Üşmûnî ve Süyûtî gibi dilciler bu görüşü Zeccâc'a nisbet etmektedir. Bk. Ebû Hayyân el-Endelüsî, İrtişâfü'd-darab min lisâni'l- 'Arab, 2/962; Üş̧mûnî, Şerhu'lÜşmûnî 'alâ Elfiyyeti İbn Mâlik, 1/114; Süyûtî, Hemu'l-hevâmi' fî̀ şerhi Cem'i'l-Cevâmi', $1 / 285$.

89 Süyûtî, Hemu'l-hevâmi' fì şerhi Cem'i'l-Cevâmi', 1/285. 
amacıyla el takısı getirilmektedir. Dolayısıyla bu tür alemlerin menkûl olduğu ortaya çıkmaktadır. ${ }^{90}$

Sîbevehy başta olmak üzere bazı dilcilere göre Arap dilinde mürtecel alem bulunmamaktadır. ${ }^{91}$ Onlara göre bütün alemler menkûl olmaktadır. ${ }^{92}$ Nitekim Ebû Hayyân şöyle bir açıklama yapmaktadır: Bazı nahivciler bütün alemlerin menkûl olduğunu iddia etmiştir. Bu, aynı zamanda Sîbeveyh'in ifadesinden de anlaşılmaktadır." 93

Bazı dilciler, alemleri menkûl ve mürtecel şeklinde iki kısma ayırmanın alemlerin çoğunluğuna yönelik bir taksim olduğunu ifade etmişledir. Onlara göre anlam bakımından genel olmakla birlikte galebe yoluyla alem haline gelen isimler ne menkûl ne de mürtecel olup vâsita konumundadirlar. ${ }^{94}$ Galebe yoluyla alem olan isimler, ifade ettikleri kişilerle tanınmış olup bu isimler zikredildiğinde onların dışında başka kişiler akla gelmeyen isimlerdir. Örneğin إِبُْ عُمَر dendiğinde Abdullah b. Ömer, أَعْشَى dendiğinde ise Meymûn b. Kays (öl. 7/629) adlı şair akla gelmektedir. Söz konusu alemler mürtecel değildir. Zira bu isimler alem olmadan önce başka bir anlamda kullanılmışlardır. Yine bunlar menkûl alemlerin kapsamına da girmemektedirler. Çünkü galebe yoluyla alem olanlarda alem için vaz' olma kastı söz konusu değildir. Halbuki menkûl alemlerde bu kasit olmalıdır. ${ }^{95}$ Kanaatimizce galebe yoluyla alem olan isimler menkûl alemlerin kapsamına girmekte ve insanların bu isimleri sürekli belirli bir kişiyi kastederek kullanmaları sonucunda alem olma özelliğini kazanmaları, vaz' mesabesinde kabul edilmektedir. ${ }^{96}$

\section{Munsarıf ve Gayr-ı Munsarıf Bağlamında Vâsıta}

Gramerciler mu'reb isimleri munsarıf ve gayr-1 munsarıf olmak üzere iki kısma ayırmaktadır. Üç hareke (damme, kesra ve fetha) ve tenvîni alabilen isimler munsarıf, cer ve tenvini alamayanlar gayr-1

90 İbn 'Akîl, Şerhu İbn 'Akîl 'alâ Elfiyyeti İbn Mâlik, 1/184.

91 Ebû Hayyân bu görüşün Sîbeveyhi'nin sözlerinden anlaşıldığını ifade etmektedir. Ancak $e l-K i t a b^{\prime}$ ta buna işaret eden herhangi bir ifadeye rastlayamadık. Bk. Ebû Hayyân el-Endelüsî, İrtişâfü'd-darab min lisâni'l- 'Arab, 2/961-962.

92 İbn Hişâm, Evdahu'l-mesâlik ilâ Elfiyyeti İbn Malik, 1/130-131.

93 Ebû Hayyân el-Endelüsî, İrtişâfü'd-darab min lisâni'l- 'Arab, 2/961-962.

94 Ebû Hayyân el-Endelüsî, et-Tezyîl ve't-tekmîl, 2/311.

95 Sabbân, Hâş̧iyetu's-Sabbân, 1/192.

96 Câmi, el-Fevâidu'd-diyâiyye, 183. 
munsarıf olarak adlandırılmaktadır. ${ }^{97}$ Gayr-1 munsarıf isimler, kesra yerine tenvinsiz zahir bir fetha ile cer edilmektedir. Onlara göre ne munsarıf ne de gayr-1 munsarıf olan isimler söz konusu değildir. Nitekim konuyla ilgili Süyûtî Hemu'l-Hevâmi' adlı eserinde şöyle bir açıklama

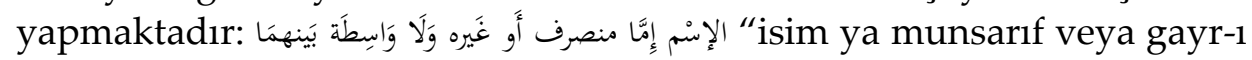
munsarıftır. Vâsıta (ne munsarıf ne de gayr-1 munsarıf) konumunda olan isimler bulunmamaktadır."98 Ancak munsarıf ve gayr-1 munsarıfın yukarıdaki tanımları göz önünde bulundurulduğunda, harflerle i'râb olan cem-i müzekker sâlim, tesniye ve esmâ-1 hamse gibi isimler her iki taksime de girmediği görülmektedir. Zira bu isimler kesra ve tenvin alamadıkları gibi cer halinde fethalı da gelmemektedirler. Ayrıca gayr-1 munsarıf olarak kabul edilen kelimelerin başına ل takısı gelir veya bir başka kelimeye muzâf olursa kesra almakla birlikte tenvîn alamamaktadır. Dolayısıyla yukarıdaki tanımlara göre bu isimler de her iki tanımın kapsamına girmemektedir. Buna göre vâsıta (ne munsarıf ne de gayr-1 munsarıf) olan isimlerin varlığından söz edilebilmektedir. Nitekim İbn Cinnî ve Ebû Ali el-Fârisî'ye göre i'râb 1 harflerle olan isimler ile başında ل takısı bulunan veya başka bir kelimeye muzâf olan gayr-1 munsarıf isimler vâsıta konumundadır.

Kanaatimizce bu tartışma, gayr-1 munsarıfın tanımından

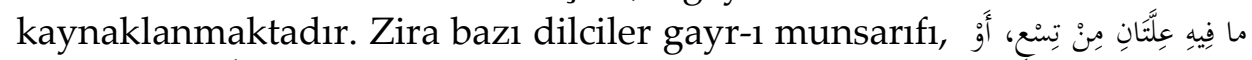

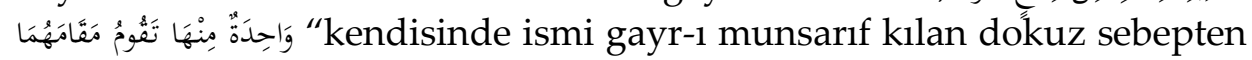
iki veya iki sebebin yerini tutan bir sebep bulunan isimdir." ${ }^{99}$ şeklinde tanımlamışlardır. Bu tanıma göre vâsıta konumunda olan isimlerden söz etmek mümkün değildir. Çünkü söz konusu sebepler bulunduğunda isim gayr-1 munsarıf, bulunmadığı zaman munsarıf olmaktadır. Örneğin أمَ'kelimesi vasıf ve veznu'l-fiil sebeplerinden dolayı gayr-1 munsarıf bir isimdir. Bu kelimenin başına "el" takısı getirip الأَمْ şeklinde telaffuz edildiğinde kelime yine gayrı munsarıftır. Zira her iki sebep devam etmektedir. Buna makabil iَ kelimesi alemiyyet ve veznu'l-fiilden dolay1 gayr-1 munsarıftır. Bu kelimenin başına "el" takısını getirince söz konusu kelime munsarıf olmaktadır. Zira íمَ'in başına "el" takısı getirmeden önce

97 İbn Serrâc, el-Usûl fi'n-Nahv, 2/79; Enbârî, Esrâru'l-arabiyye, 54.

98 Süyûtî, Hemu'l-hevâmi' fì şerhi Cem'i'l-Cevâmi', 1/133.

99 İbnu'1-Hâcib, el-Kâfiye fi'n-nahv, 2010), 1/12. 
onu nekire haline (Ahmed adında herhangi bir kişi) getirmek gerekmektedir. Çünkü "el" takısı marife olan ismin başına getirilemez.

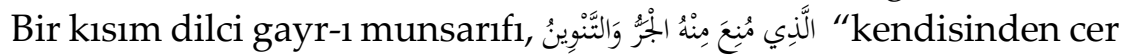

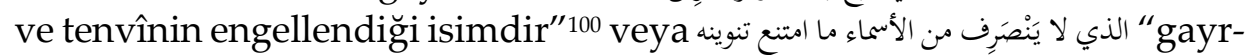
1 munsarıf isimler, tenvin alamayanlardır." 101 biçiminde tarif etmişlerdir. Bu iki tanıma göre vâsıta (ne munsarıf ne de gayr-1 munsarıf) olan isimlerden söz etmek mümkündür. Zira harflerle i'râb olan cem-i müzekker sâlim, tesniye ve esmâ-ı hamse gibi isimler ile gayr-1 munsarıf olarak kabul edilen kelimelerin başına ل takısı gelen veya bir başka kelimeye muzâf olan isimler ne munsarıf ne de gayr-1 munsarıf kapsamına girmektedir. Ancak gayr-1 munsarıfın doğru tanımı ilk tanımdır. Nitekim bazı dilciler gayr-1 munsarıfı bu tanımla tarif ettikten

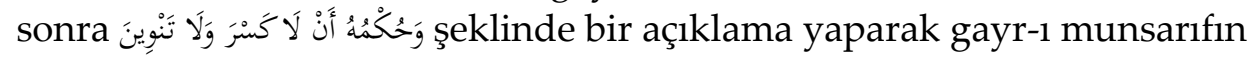
cer ve tenvin almamasının bir sonuç olduğuna işaret etmektedir. ${ }^{102}$

\section{Sonuç}

Çalışmamızda dilcilerin mu'reb veya mebnî, ma'rife veya nekire gibi ikili isim taksimine dâhil etmekte zorlandıkları ve bunun için "vasıta" kavramını kullanarak üçüncü bir konumda göstermeye çalıştıkları isimler ve bunlar etrafındaki tartışmalar ele alınmıştır.

Yapılan araştırmada isim "ya mu'reb veya mebnidir" şeklindeki ikili taksimin kapsamına girmediği iddia edilen isimler şunlardır:

1- Yalın hâldeki isimler. Dilcilerin cumhuruna göre, cümle içinde kullanılınca i'râb aldıklarından bu isimler mu'reb olarak kabul edilirken, bazıları onları mebnî isimlerin kategorisine almışlardır. Söz konusu isimleri mu'reb olarak kabul etmenin daha doğru bir yaklaşım olacağı tespit edilmiştir.

2- Müfred-ma'rife ve nekra-i maksûde olan münâdâ isimler. Bazı dilciler bunları mebnî kabul etmiş, bazıları mu'reb saymış, diğer bir kısım dilciler ise bunları vâsıta (ne mu'reb ne de mebnî) kategorisine almıştır. Ancak söz konusu isimlerin mebnî olduklarına dair görüşün daha isabetli olduğu görülmüştür.

3-Mütekellim yâ'sına izâfe edilen isimler. Bu isimlerin binâ ve i'râbı hakkında üç farklı görüşün olduğu tespit edilmiştir. Mu'reb olup

\footnotetext{
100 Meylânî, Şerhu'l-muğnn̂ fi'n-nahv, 10.

101 İbn Mâlik, Şerhu Teshîli'l-Fevâid, 1/41.

102 İbnu'l-Hâcib, el-Kâfiye fi'n-nahv, 12.
} 
446 | M. TAŞ / Arap Dilinde İsmin İkili Taksiminde Vâsita Olgusu

ref' ve nasb durumlarında irabları takdîrî, cer konumunda ise lafzî olduğunu belirten görüş daha isabetli bir görüştür.

4- Belirli bir günün seherinin kastedildiği سَخَ kelimesi. Bu kelimeyi mu'reb-munsarıf olarak kabul eden Şelevbîn ve Süheylî́nin görüşü daha makul bir yaklaşım olarak görülmüştür.

5- Zarf ve alem olan أَمْس kelimesi. Bu kelimenin mebnî olduğuna dair görüşün daha doğru olduğu tercih edilmiştir.

6- Sonunda itbâ harekesi bulunan ve soru edatı olan مَ'den sonra gelip mahkî irâb alan alem isimler. Serdettikleri deliller bakımından söz konusu isimlerin mu'reb olduğuna dair cumhûrun görüşünün daha güçlü olduğu tespit edilmiştir.

Bazı dilciler, Arap dilindeki tüm isimler "ya ma'rife veya nekiredir" şeklindeki ikili taksime dâhil olmayan bazı isimlerin varlığından söz etmişlerdir. Onlara göre "el" takısı ve tenvîn alamayan istifhâm edatları olan مَّا, مَنْ, أَيْنَ, مَتى vibi ve visimler ne ma'rife ne de nekiredir. Ancak bu soru edatlarının nekire isimlerin kapsamına girdiği tespit edilmiştir.

ve türevlerinin zâhir isimlerin mi zamirlerin mi yoksa ne zâhir ne de zamirlerin mi kapsamına girdiği hususu dilciler arasında tartışma konusu olmuştur. Ancak bu kelimelerin zamir isim kategorisinde olduğu, Arap dilindeki bütün isimlerin ya zâhir veya zamir olup vâsıta (ne zâhir ne de zamir) konumunda olan isimlerin söz konusu olmadığ görülmüştür.

Arap dilindeki bütün zamirler ya muttasıl veya munfasıldır. Ancak bazı dilciler bu taksime itiraz etmekte ve müstetir zamirlerin vâsıta konumunda olup ne muttasil ne de munfasıl zamirlerin kapsamina girdiğine dair bir görüş ileri sürmektedirler. Zira ittisâl ve infisâl vücutta varlığı bulunan lafızlara özgü bir özelliktir. Müstetir zamirlerin vâsıta konumunda olduğuna dair görüşün daha isabetli olduğu görülmüştür.

Arap dilindeki bütün alemleri menkûl veya mürtecel şeklinde iki kısma ayırmak alemlerin çoğunluğuna yönelik bir taksimdir. Nitekim galebe yoluyla alem haline gelen isimler ne menkûl ne de mürtecel olup vâsita konumundadır.

Gramercilerin cumhuruna göre mu'reb isimler munsarıf ve gayr-1 munsarıf olmak üzere iki kısma ayırılmakta olup vâsıta (ne munsarıf ne de gayr-1 munsarıf) konumunda olan isimler söz konusu değildir. Buna 
karşılık bazıları bu taksimdeki vâsıta olgusunu kabul etmektedir. Kanaatimizce bu tartışma, gayr-1 munsarıfın tanımından kaynaklanmaktadır.

Netice itibariyle, "ya mu'reb veya mebnîdir", "ya ma'rife veya nekiredir", "ya zamir veya zâhirdir" şeklindeki ikili taksime dâhil olmayıp vâsita konumunda olan isimlerden söz etmek zorlama bir yaklaşımdır. Ancak "zamirler ya muttasıl veya munfasıldır", "alemler ya menkûl veya mürteceldir", "mu'reb isimler ya munsarıf veya gayr-1 munsarıftır" biçimindeki ikili taksimin kapsamına girmeyip vâsıta konumunda olan isimlerden söz etmek ihtimal dahilindedir.

\section{Kaynakça}

Ahfeş el-Evsat, Ebu'l-Hasen Saîd b. Mes'ade. Me'âni'l-Kur'ân. 4 Cilt. Kahire: Mektebetu'l-Hâncî, 1990.

Câmî, Nûruddîn 'Abdurrahmân b. Nizâmiddîn Ahmed b. Muhammed el-Câmi. el-Fevâidu'd-diyâiyye. Asitâne: Matbaatu'l-Hâc Muharrem Efendi, 1281.

Ebû Hayyân el-Endelüsî, Muhammed b. Yûsuf b. Alî b. Yûsuf b. Hayyân. et-Tezyîl ve't-tekmîl fî şerhi Kitâbi't-Teshîl. thk. Hasan Hindâvî. 11 Cilt. Dimaşk: Dâru'l-Kalem, 1. Basım, ts.

Ebû Hayyân el-Endelüsî, Muhammed b. Yûsuf b. 'Alî b. Yûsuf b. Hayyân. İtişâfü'd-darab min lisâni'l- 'Arab. thk. Receb Osman Muhammed. 5 Cilt. Kahire: Mektebetu'l-Hancî, 1998.

Ebu'l-Fidâ', el-Meliku'l-Müeyyed 'İmâdüddîn İsmâîl b. 'Alî b. Mahmûd el-Eyyûbî. el-Kennâş̧ fî fenneyi'n-nahvi ve's-sarf. thk. Riyâd b. Hasan el-Havâm. 2 Cilt. Beyrut: el-Mektebtu'l-'Asriyye, 2000.

Enbârî, Ebu'l-Berekât Abdurrahmân b. Muhammed. el-İnsâf fî mesâili'lhilâf beyne'n-nahviyyîn. 2 Cilt. el-Mektebetu'l-'Asriyye, 2003.

Enbârî, Ebü'l-Berekât Kemâlüddîn Abdurrahmân b. Muhammed b. Ubeydillâh. Esrâru'l-arabiyye. Dâru'l-Erkam, 1999.

Esterâbâdî, Necmü'l-Eimme Radıyyüddîn Muhammed b. el-Hasen. Şerhu'r-Radî 'ale'l-Kâfiye. thk. Hasan b. Muhammed b. İbrâhîm Yahyâ Beşîr Mustafâ. Riyad: Camiatu'l-İmam Muhammed b. Suud el- İslamiyye, 1417.

Ezherî, Ebu'l-Velîd Zeynuddîn Hâlid b. 'Abdillâh b. Ebî Bekr. Şerhu'ttasrîh 'ala't-tevdîh. 2 Cilt. Beyrut: Dâru'l-Kutubi'l-'İlmiyye, 2000. 
448 | M. TAŞ / Arap Dilinde İsmin İkili Taksiminde Vâsita Olgusu

Fârisî, Ebû 'Alî Hasan b. Ahmed b. 'Abdilgaffâr. et-Ta'lîka 'alâ Kitâbi Sîbeveyh. thk. 'Avd b. Hamd el-Kûzî. 6 Cilt. (b.y.: y.y., 1410/1990).

Halîl b. Ahmed. Kitâbu'l-'ayn. thk. Abdülhamid Hindâvî. 4 Cilt. Beyrut: Dârüu'l-Kutubi'l-'İlmiyye, 1424/2003.

Hudarî, Muhammed b. Mustafâ b. Hasan. Hâşiyetü'l-Hudarî 'alâ Şerhi İbni 'Akîl. 2 Cilt. Beyrut: Dâru'1-Fikr, 2003.

İbn 'Akîl, Ebû Muhammed Bahâuddîn 'Abdullah b. 'Abdirrahmân b. Akîl. Şerhu İbn 'Akîl 'alâ Elfiyyeti İbn Mâlik. thk. Muhammed Muhyiddin Abdulhamid. 4 Cilt. Kahire: Dâru't-Turâs, 1980.

İbn Bâbşâz, Tahir b. Ahmed. Şerhu'l-mukaddimeti'l- muhassibe. thk. Hâlid Abdülkerîm. 2 Cilt. b.y: el-Matbaatu'l-Asriyye, 1977.

İbn Cinnî, Ebu'l-Feth Osmân b. Cinnî el-Mevsılî. el-Hasâis. 3 Cilt. Kahire: el-He'yetu'l-Misriyye el-Âmme li'l-Kitâb, ts.

İbn Cinnî, Ebu'l-Feth Osmân el-Mevs1lî. el-Muhteseb fì tebyîni vucûhi şevâzzi'l-kırââti ve'l-îdâhi 'anhâ. 2 Cilt. Kahire: Vizâretu'l-Evkâf elMeclisu'l-A'lâ li'ş-Şuûni'l-İslâmiyye, 1999.

İbn Hişâm, Ebû Muhammed Cemâluddîn 'Abdullâh b. Yûsuf b. 'Abdillâh b. Hişâm el-Ensârî. Şerhu katri'n-nedâ ve belli's-sadâ. thk. Muhammed Muhyiddîn 'Abdulhamid. Kahire: y.y., 1383.

İbn Hişâm, Ebû Muhammed Cemâluddîn 'Abdullâh b. Yûsuf b. Hişâm el-Ensârî. Evdahu'l-mesâlik ilâ Elfiyyeti İbn Malik. thk. Yusuf eş-Şeyh Muhammed el-Bukâî. 4 Cilt. Beyrut: Daru'l-Fikri li't-Tibâ'ati ve'nNeşr, ts.

İbn Mâlik, Ebû 'Abdillâh Cemâluddîn Muhammed b. 'Abdillâh b. Mâlik et-Tâî. el-Elfiyye. thk. Süleyman b. Abdülaziz. Riyad: Mektebetu Dâri'l-Minhâc, 1428.

İbn Mâlik, Ebû 'Abdillâh Cemâluddîn Muhammed b. 'Abdillâh b. Mâlik et-Tâi. Şerhu Teshîli'l-Fevâiid. thk. Muhammed Bedevî el-Mahtûn. 4 Cilt. Kahire: Mektebetu Hecer, 1990.

İbn Manzûr, Ebu'l-Fadl Cemâlüddîn Muhammed b. Mükerrem. Lisânu'l'Arab. 15 Cilt. Beyrut: Dâru Sâdır, 1414.

İbn Serrâc, Ebû Bekr Muhammed b. es-Serî b. Serrâc. el-Usûl fi'n-Nahv. 3 Cilt. Beyrut: Müessesetu'r-Risâle, ts.

İbn 'Usfûr, Ebü'l-Hasen Alî b. Mü'min b. Muhammed b. Alî el-Hadramî el-İşbîlî. Şerhu'l-Cümel. thk. Fevvâz eş-Şa'âr. 3 Cilt. Beyrut: Dâru'lKutubi'l-'İlmiyye, 1419/1998. 
İbn Ya'îş, Ebu'l-Bekâ Muvaffakuddîn Yaîş b. Alî b. Yaîş. Şerhu'l-Mufassal. 6 Cilt. Beyrut: Dâru'l-Kutubi'l-'Illmiyye, 2001.

İbnu'l-Hâcib, Ebû Amr Cemâlüddîn Osmân b. Ömer. el-Kâfiye fi'n-nahv. thk. Sâlih 'Abdulazîm. Kahire: Mektebetu'l-Âdâb, 2010.

İbnu'l-Hâcib, Ebû Amr Cemâlüddîn Osmân b. Ömer. Şerhu'l-vâfiye nazmu'l-Kâfiye. thk. Mûsâ Bennâî Alevân el-Alîlî. Necef: Matbaatu'lÂâb, 1400.

İbnu'n-Nâzım, Ebû 'Abdillâh Bedruddîn Muhammed b. Muhammed b. Abdillâh b. Mâlik. Şerhu İbni'n-Nâzım 'alâ Elfiyyeti İbni Mâlik. thk. Muhammed Bâsil ‘Uyûnu's-Sûd. Beyrut: Daru'l-Kutubi'l-'İlmiyye, 2000.

İbnü'ş-Şecerî, Ebü's-Saâdât Ziyâüddîn Hibetullah b. Alî b. Muhammed b. Hazma. el-Emâlî. thk. Mahmûd Muhammed et-Tanâhî. 3 Cilt. Kahire: Mektebetü'l-Hâncî, ts.

İbnu'l-Vecîh, Ebû Muhammed Necmüddîn (Tâcüddîn) Abdullâh b. Abdilmü'min b. el-Vecîh el-Vâsitî. el-Kenz fi'l-kırââti'l-'aşr. thk. Halid el-Meşhedânî. 2 Cilt. Kahire: Mektebetü's-Sekâfeti'd-Diniyye, $1425 / 2004$.

Meylânî, Muhammed b. 'Abdirrahîm el-Ömerî. Şerhu'l-muğnî fi'n-nahv. Dersaadet: Mektebetu's-Sanâyi', 1311.

Müberred, Ebü'l-Abbâs Muhammed b. Yezîd b. Abdilekber b. Umeyr. Muktedab. thk. Muhammed Abdülhalık 'Azîme. Beyrut: 'Âlemü'lKütüb, ts.

Murâdî, Ebû Muhammed Bedruddîn Hasan b. Kâsım b. 'Alî. Tavdîhu'lmesâlik ve'l-makâsid bi şerhi Elfiyyeti İbni Mâlik. thk. 'Abdurrahmân 'Alî Süleyman. 3 Cilt. Kahire: Dâru'l-Fikri'l-'Arabî, 2008.

Sabbân, Ebu'l-'İrfân Muhammed b. 'Alî. Hâş̧iyetu's-Sabbân 'alâ Şerhi'lÜşmûnî. 3 Cilt. Beyrut: Dâru'l-Kutubi'l-'İlmiyye, 1997.

Süheylî, Ebu'l-Kâsım Abdurrahmân b. Abdillâh b. Ahmed. Netâicu'l-fiker fi'n-nahv. Beyrut: Dâru'l-Kutubi'l-İlmiyye, 1992.

Süyûtî, Celâluddîn Abdurrahmân b. Ebî Bekr. el-Eşbâh ve'n-nazâir fi'nnahv. thk. Abdulâl Sâlim Mükerrem. 4 Cilt. Beyrut: Müessesetu'rRisâle, 1406.

Süyûtî, Celâluddîn Abdurrahmân b. Ebî Bekr. Hemu'l-hevâmi' fì şerhi Cem 'i'l-Cevâmi'. thk. 'Abdulhamîd el-Hindâvî. 3 Cilt. Misır: elMektebetü't-Tevfîkiyye, ts. 
450 I M. TAŞ / Arap Dilinde İsmin İkili Taksiminde Vâsita Olgusu

Sîbeveyhi, Ebû Bişr Amr b. Osmân b. Kanber el-Hârisî. el-Kitâb. thk. Abdüsselâm muhammed Hârûn. 4 Cilt. Kahire: Mektebetü'l-Hâncî, 1408/1988.

Şâtıbî, Ebû İshâk İbrâhîm b. Mûsâ b. Muhammed. el-Makâsidu'ş-şâfiye fi şerhi'l-Hulâsati'l-Kâfiye. thk. Muhammed İbrâhîm el-Bennâ. 10 Cilt. Mekke: Ma'hedu'l-Buhûsi'l-'İlmiyye ve İhyâu't-Turâsi'l-İslâmî, 2007.

'Ukberî, Ebu'l-Bekâ Muhibbuddîn 'Abdullah b. el-Huseyn. el-Lubâb fì 'İleli'l-i'râbi ve'l-binâ'. thk. 'Abdulillâh en-Nebhân. 2 Cilt. Dimaşk: Dru'l-Fikr, 1995.

Üşmûnî, Ebu'l-Hasan Nuruddîn 'Alî b. Muhammed b. 'Îsâ. Şerhu'lÜşmûn̂̀ 'alâ Elfiyyeti İbn Mâlik. 4 Cilt. Beyrut: Dâru'l-Kutubi'l‘İlmiyye, 1998.

Yâsîn b. Zeynuddîn. Hâşiytu Yâsîn ala't-tasrîh. Kahire: el-Matb'atu'lEzheriyye, 1326.

Zemahşerî, Ebu'l-Kâsım Mahmûd b. Ömer b. Muhammed. el-Keşşâf 'an hakâikı ğavâmidi't-tenzîl ve 'uyûni'l-ekâvîl fî̀ vucûhi't-te'vîl. 4 Cilt. Beyrut: Dâru'l-Kitâbi'l-'Arabî, 1407.

Zemahşerî, Ebü'l-Kâsım Mahmûd b. Ömer b. Muhammed el-Hârizmî. elMufassal fí sinâ'ati'l-i'râb. thk. 'Ali Ebû Malahham. Beyrut: Mektebetu'l-Hilâl, 1993. 